Scheepers, C. B., Douman, A., \& Moodley, P. (2018). Sponsorship and social identity in advancement of women leaders in South Africa. Gender in Management: An International Journal, accepted and in press: GM06-2017-0076.

\title{
Sponsorship and social identity in advancement of women leaders in South
}

\author{
Africa \\ Caren Brenda Scheepers, Anastasia Douman and Preya Moodley \\ Gordon Institute of Business Science, University of Pretoria, Johannesburg, South Africa \\ Short running title: Sponsorship Social Identity Women RSA GM-06-2017-0076-R1
}

\begin{abstract}
Purpose: In South Africa women in senior management positions experience social identity dilemmas, necessitating more research into this domain. While research has been conducted into coaching and mentoring of these women, limited scholarly attention has been paid to sponsorship. This paper thus explored the social identity of women at senior management levels as well as sponsorship as a proposed mechanism to develop talented women.

Design/methodology/ approach: This qualitative research included two studies using two sample groups, both of which included executive level respondents in corporate organisations. One study focussed on sponsorship; here the 29-strong sample included 14 male and 15 female executives, of whom 15 were White; nine were African and five Indian. The second study, consisting of only African, Coloured and Indian (ACI) women executives (23 interviewees), focussed more broadly on their development path to the C-suite.
\end{abstract}

\section{Findings:}

A common theme across the two studies was the inclination to give developmental support, in turn, once supported. There were prerequisites in this support-giving, however. For example, 
sponsors identified criteria that protégés had to meet. Despite evident gender inequality at senior management levels in South Africa, this paper reveals that in the Study 1 sample, gender as well as race were ostensibly irrelevant when choosing a sponsor or who to sponsor. A closer examination revealed a gender-based expectation, embedded in the South African context. Study 2 showed that ACI women above 50 years of age were more inclined to mentor others; even when they themselves were not mentored, some purposefully developed other ACI women. This paper thus suggests age as an important additional diversity dimension in relation to the career development of ACI women towards the C-suite. The findings have implications for the career development of individual ACI women and for organisations in reaching equality. Gender differences with regards to perceptions also revealed that male respondents perceived sponsorship more as task-based actions, whereas female respondents focussed on relational elements. The paper concludes with recommendations on how individual ACI women and organisations can proactively develop talented women.

Originality/ value: The paper offers insight into the gendered expectations of sponsors and gendered perceptions around merit in identifying protégés worthy of sponsorship. ACI women's social identity changed when they joined the C-suite to identify more with their roles as executives, and became less associated with their original ACI women group.

Keywords: Women, Inequality, Mentoring, Identity, Talent, Sponsorship; Queen-bee syndrome; Age; Gendered expectations

Paper type: Research Paper

\section{Introduction}

The majority of previously disadvantaged women, namely African, Indian and Coloured (ACI) women, experience challenges migrating economically as managerial positions in South Africa continue to be retained mainly by white males, who comprise two thirds of employees (67.6 
per cent) (Department of Labour, 2016). The main objective of this study was to deepen understanding of the advancement of ACI women to top managerial positions by exploring the lived experience of a sample of ACI women executives in the South African context. The enablers to their advancement were studied and of special interest was the intersectionality of race and gender in their experience, both in being developed and, in turn, in developing others.

While the extant literature reveals that several studies on mentoring and coaching have been conducted, limited scholarly attention has been paid to sponsorship as a talent management intervention for women leaders aspiring to senior levels. 'To sponsor' means 'to pledge', or give assurance, and thus sponsorship, in the context of corporates, is defined as the public support by a powerful, influential person for the advancement and promotion of an individual within whom he or she has identified untapped or unappreciated leadership talent or potential (Helms et al, 2016). Playing the role of sponsor would thus include public support that places the sponsor's reputation at risk, should the protégé not live up to the organisation's expectations. For this reason, the authors made the assumption that mentoring, as a development practice, would be more readily available than sponsorship, and tested this assumption in the study. As a small sample of ACI women was targeted for the in-depth semistructured interviews, and the authors thought the interviews with these women would offer limited information on sponsorship, the authors decided to conduct another study to focus specifically on sponsorship as a talent development intervention.

In South Africa, only 23 per cent of positions involved in making economic decisions are occupied by women (Hills, 2015) and only four per cent of CEO positions are filled by women (Moodley, Holt, Leke \& Desvaux, 2016); the number of senior women sponsors is therefore limited. For this reason, the authors decided to include males in their sample to specifically examine sponsorship as a talent development practice. The sponsors' perspectives were 
important, in addition to those of the protégé or person being sponsored, and thus a mixed gender sample was chosen for this study.

At the current rate of new appointments of women to senior roles it will take 84 years for the gender gap to be completely eradicated worldwide, implying that a female child born today may, in her lifetime, experience complete gender equality (World Economic Forum, 2016). Intentional growth and development of women is required to improve this situation and this research therefore set out to contribute to the body of knowledge on ACI women in the C-suite.

\section{Conceptual background}

\section{Talent management interventions}

Organisations offer several talent management interventions to mitigate the challenges faced by women. Mentoring, for example, is a relationship in which a more knowledgeable or experienced person provides career guidance to a person who seeks to attain career capital (Ensher \& Murphy, 1997); the mentor is expected to encourage and support the individual, and ensure professional development of the less experienced person (Joo, Sushko \& McLean, 2012). Athey, Avery and Zemsky (2000) found that the ability of entry-level employees is increased by mentoring.

The role of gender in mentoring relationships is relevant to this study, since female mentors are especially important for women as they can serve as role models and the same-sex mentoring relationship will not have the detrimental sexual connotations cross-sex relationships reportedly elicit (Ragins \& Scandura, 1994). Gender differences also exist with regards to women who expect more from mentoring relationships than males (Ragins \& Scandura, 1994). Mentoring comprises two different functions: psychosocial and professional advancement (Fitzsimmons \& Callan, 2016). Professional advancement comprises "sponsorship, coaching, protection, exposure, visibility, and the provision of challenging career 
assignments, so providing both social capital and opportunities to refine and increase other valuable capitals" (Fitzsimmons \& Callan, 2016, p. 8). The psychosocial functions include "encouragement, friendship, advice, and feedback, as well as helping individuals to develop a sense of competence, confidence, and effectiveness" (Fitzsimmons \& Callan, 2016, p. 8). From these definitions it appears that sponsorship and coaching are forms of mentoring. However, Tee Ng (2012) explains that mentoring is more focused on learning towards development into an expert, and takes a medium- to long-term perspective. He further contends that mentoring is not to be confused with coaching, which is more focused on learning for execution, and takes a short- to medium-term viewpoint.

Leadership coaching is the coaching of executives and managers aspiring to leadership positions (Scheepers, 2012). It involves counselling to improve leadership effectiveness by addressing issues encountered in the organisation (Ladegard \& Gjerde, 2014). Lin, Wang, Bamberger, Zhang, Wang, Guo, Shi and Zhang (2016) argue that high levels of coaching benefit employees by providing more significant understanding of how to set career objectives, frame career objectives and fulfil these objectives. The South African study by Johnson and Mathur-Helm (2011) suggests mentoring, coaching and job shadowing, and proposes women advancement programmes for senior women to support other women.

Networking helps people find jobs, move within the organisation as well as work around policies and procedures; it also assists with promotions as well as pay increases, which ultimately lead to job satisfaction (McCallum, Forret \& Wolff, 2014). Sponsors open up their networks to their protégés and galvanize the support of others by using political clout to navigate key people. This means that in sponsorship relationships, one of the key elements required for career advancement is made available to protégés. The authors intended to explore the perceptions of sponsors in particular and therefore had to include top management in their sample. Scholars like McIntosh, McQuaid and Munro (2015) highlight that gender perceptions, 
by both males and females, can be biased against women, and these produce gender inequalities in employment. For this reason, focussed attention is required to develop women's talent in organisational settings, through leadership training or team-building programmes, which encourage self-reflection of both men and women around gender-based assumptions and expectations, as Ely, Ibarra and Kolb (2011) recommend. Ragins and Scandura (1994) advise that having a mentor is related to career advancement and facilitating the advancement of women has a synergistic effect in promoting women's mentoring relationships and their future advancement.

\section{Social identity theory}

Social identity theory holds that people tend to group themselves, as well as others, into social categories and that these groupings significantly affect human affiliations. Booysen (2007) argues that South Africans have numerous concurrent identities with various social groups. Bernard-Powers (2008) says, "gender does not function in social isolation: it is shaped by multiple identities in specific historic, political, and economic contexts" (p. 315). According to Tajfel and Turner (1979), social identity theory was created to address situations covering both intergroup relations and social change. In-group characteristics are understood and formulated by comparison to the out-group, thereby deriving value from the in-group (Tajfel $\&$ Turner, 1979). Through a social character framing process, the demographic minority may then be classified as an out-group by the dominant group (or in-group). The greater group builds up an intelligibility and certainty that strengthens their self-regard and self-recognition (Tajfel \& Turner, 1986).

Social identity threats are inclined to lead the group to stronger identification (Tajfel, 1978). The authors of this paper argue that this is highly applicable to the South African setting, as demonstrated during the dawn of democracy when people of colour were unified in their bid 
for freedom. Tran, Garcia-Prieto and Schneider (2011) further state there is an emotional connection towards this group by individuals who recognise themselves within these social categories. Individuals perceive fewer gender barriers, compared to the past, as they migrate towards the C-suite and there is more perceived equality; this results in women feeling less apprehensive, but also less associated with their social group (Park, 2013). A deeper understanding was thus required into whether ACI women maintain their social identity or adapt to, and even identify with, the white male-dominated environment (Eagly \& JohannesenSchmidt, 2001). This is particularly important as a social identity change could cause them not to mentor [or even sponsor] other women (Park, 2013). We thus set out to explore the experiences of the ACI women in our sample and whether their identity with their social group had changed, as this influences whether they would create environments conducive for aspirant C-suite women to grow and fulfil their potential.

\section{Literature review}

\section{Gender and sponsorship or mentoring}

O'Reilly (2008) emphasises that mentoring other women makes women's jobs rewarding and productive. Women who were mentored by other women vowed to return the favour and help other women in the workplace. O’Neill and Blake-Beard (2002) report that the historical shortage of women in advanced managerial positions has led to a shortage of female mentors, as well as female mentor-male protégé relationships. The potential for real or perceived sexual involvement is one of the barriers to cross-gender mentoring relationships (Griffin \& Reddick, 2011). These researchers also point out that women may not be chosen as protégés since gender stereotyping may lead to women being perceived as having fewer managerial skills and less ability to balance career and family demands. Gender stereotyping also leads to women being less likely to be chosen as mentors. O’Neill and Blake-Beard (2002) 
also warn there are potential negative outcomes for mentors through their association with protégés who do not meet expectations. We would extend this finding to argue that when it comes to sponsorship, which requires public support, the danger of potential negative outcomes from sponsoring failing protégés would be even greater. O’Neill and Blake-Beard (2002) emphasise that women mentors anticipate more drawbacks than men of being a mentor. In the case of sponsorship, this reluctance to engage would be even greater, as the stakes are higher for women sponsors. Gender stereotyping places extra pressure on women to perform and show leadership competence or, in this case, sponsorship discernment (or choosing who to sponsor). Women who have broken through the glass ceiling, and ACI women in particular, in the South African context, may limit aspiring ACI women's entry into senior roles and would thus not set out to mentor or sponsor other women. This would pose a huge threat to gender equality, since it would influence the career development of potential protégés. Extant literature describes such women as queen bees. Vachon (2014) defines queen bees as women who have managed to attain leadership roles in industries previously dominated by men, and then use these positions of power to prevent other women from attaining the same success. Derks, Van Laar and Ellemers (2016) note that women can "adopt" the queen bee syndrome in one of the following three ways: by presenting themselves more like men, by physically and psychologically distancing themselves from women, or by endorsing and legitimising the current gender hierarchy. Women might deny that other women face difficulties in the workplace, or they may view other women as a threat and therefore opt to surround themselves with men. Derks et al (2016) state that women who have achieved success despite gender bias see themselves as superior to other women. A specific research question around the critical success factors that enable ACI women to progress to $C$-suite was therefore formulated. The research also examined factors that led to the respondents' interest or disinterest in developing aspirant ACI C-suite women. 
Skaggs, Stainback and Duncan (2012) contend that it is essential to have more than one woman in executive positions, as women derive their strength through numbers and this encourages female support for other women. What form would this support take? With reference to the talent management section above, would women purposefully mentor or even sponsor other women, especially since sponsorship would go further than mentoring, by visibly and sometimes financially supporting other women? This study set out to explore whether our assumptions of limited sponsorship, and specifically limited sponsorship of other women, were correct in an ACI women sample.

Our research questions thus included whether gender played a role in terms of who was better placed to sponsor women or be sponsored, and ultimately whether sponsorship contributed to advancement into leadership roles for the executives in this study.

Having more women in executive positions prevents them adopting the agentic traits usually associated with men, including assertiveness, independence or competitiveness (Rosette \& Tost, 2010). Senior women perceive themselves as more agentic (Eagly \& JohannesenSchmidt, 2001) and career driven than junior women. Junior women's careers are influenced positively by having women role models or mentors (Hurley \& Choudhary, 2016). According to Elstad \& Ladegard (2012), previously male boards that employ women to gain specialised skills on the board send positive messages to internal and external stakeholders. Consequently, they have more participative boards and build better reputations. The question remains whether these male boards perceive women as having adequate talent to sponsor them to develop their skills to make a meaningful contribution to the board? A seminal but disconcerting study by Kumra (2017) points out that merit is in fact far from being an objective measure of ability. Instead, merit is deeply rooted in the contextual and gendered understanding of contribution and organisations are thus no longer able to rely solely on their discourses on meritocracy to show their commitment to addressing gender inequalities. She shows that embedded 
inequalities necessitate wider societal understanding of meritocracy and the limitations of perceptions around it. The authors of the current study believe the findings by Kumra (2017) may be applicable to the intersectionality of gender and race, and that ACI women suffer double jeopardy and thus are even less likely be perceived as worthy and deserving of merit awards.

Studies have found gender differences in perceptions about interactive styles of management; females were more likely than males to indicate that they use an interactive style of management and they reported higher perceived effectiveness of coaching and developing others (Burke \& Collins, 2001).

\section{Race and sponsorship or mentoring}

Griffin and Reddick (2011) report in their US-based study that Black professors were more likely to engage in mentoring than their White colleagues. They found that where race and gender intersect, as with Black women professors, the expectation to play a nurturing role, like mentoring, was even greater. Their study also points out that while mentoring is rewarding, it is also time-consuming for these Black women professors; they are, however, expected to spend this extra time mentoring. Interestingly, where only race as identity was involved, such as Black male professors, mentors engaged in more formal, distant and compartmentalised ways with their protégés. Mentoring patterns are thus not determined by race alone and individuals experience environmental phenomena differently on the basis of the conflation of their social identities.

In South Africa, race is a central feature in the social identity of individuals. However, when an aspiring ACI woman does overcome all obstacles, and breaks through the glass ceiling, it creates an extra social identity dimension and perhaps the previously disadvantaged status of the woman, and belonging to a particular racial group, are no longer relevant. 
The Employment Equity Act 2003 (EE) and Broad Based Black Economic Empowerment Act of 2013 (BBBEE), legislated by the post-apartheid South African government, strive to remedy the racial and gender distortion of the past. Regrettably, after 24 years of democracy, South Africa continues to battle inequality in the workplace. Furthermore, the Department of Labour (2016) confirms that these Acts have been ineffective in improving the labour force participation rate, as unemployment is at 26.4 per cent while female youth unemployment (15-34 years) sits at 40.7 per cent (Statistics South Africa, 2015: 12). Numerous articles regarding gender inequality, as well as affirmative action policies for marginalised groups (Fernandez \& Lee, 2016; Harnois, 2015; Kaiser \& Spalding, 2015; Park, 2013), were reviewed for this study - yet limited research was found to determine the enabling factors utilised by racially marginalised groups to access the $\mathrm{C}$-suite.

Corlett and Mavin (2014), in their introduction to the Special Issue in Gender in Management on "Intersectionality, Identity and Identity work", point to the overlapping of inequalities where the intersection of two minority categories (Black and woman) constitute a distinct social position (Black woman). The whole produces unique forms of disadvantage which are more than the sum of the single categories. Of particular interest in the current study are the self-identities of the ACI women interviewed, which consisted of multiple social identities, since the lived experience and subjectivities of these women were explored. The intersection between gender and other identities, race in particular, was prominent in the current study. Intersectionality research highlights the danger of treating all differences equally. In the current study, the authors acknowledge that ACI women's multiple social identities intersect in complex ways that lead to multiple self-identities. Due to South Africa's history of social divide based on race, the social identity of race has prominence in the classification of people and thus would also have importance within their multiple social identities. Griffen and Reddick (2011) also highlight the importance of intersectionality to address the dynamic 
processes through which the multiple social identities to which individuals subscribe converge to share their experiences. Membership of multiple identity groups can affect how people are perceived and treated. This study thus endeavours to distinguish the ways in which individuals engage their environments based on multiple identities. The study explores how multiple identities, particularly race and gender, simultaneously influenced the ACI women's beliefs and practices when mentoring and being mentored.

\section{Social identity theory and leadership}

Eagly and Johannesen-Schmidt (2001), emphasise that perceptions regarding females and leadership roles create incongruity, because leadership is mainly associated with male roles. Therefore, when men behave agentically, it is regarded as the norm. Conversely, when women do the same, they encounter prejudice, because of stereotypical qualities women are expected to portray (Eagly \& Karau, 2002). Rosette and Tost (2010) refer to this behaviour of men towards agentic women as backlash. Fitzsimmons and Callan (2016) propose that two areas of development are required, namely developing human capital and developing social capital. Women focus on completing tasks at work first, thus limiting the opportunity to network, which diminishes the opportunity to develop social capital, as they are balancing family and work life. By not developing social capital, women limit themselves; they become invisible, creating limitations for line roles. The social identity theory of leadership views leadership as a group process, engendered by social categorisation and prototype-based depersonalisation processes, associated with social identity (Hogg, 2001).

Role incongruity could limit the careers of women (Rosette \& Tost, 2010). For example, there exists a "double bind" or "feminine competency bind" in which acting feminine is regarded as acting incompetently, and acting competently as acting masculine (Appelbaum, Audet \& Miller, 2003). The role congruity theory of prejudice toward female leaders proposes 
that perceived incongruity between female gender roles and leadership roles leads to two forms of prejudice: perceiving women less favourably than men as potential occupiers of leadership roles, and appraising behaviour that fulfils the prescriptions of a leader role less positively when it is enacted by a woman (Rosette \& Tost, 2010).

Eagly and Johannesen-Schmidt, (2001) argue that women who adopt agentic traits may not add the diversity required from their transformational role, hence limiting the diversification that they could have contributed to the organisation.

\section{Challenges of sponsorship or mentoring}

In cases where the sponsor and protégé, or mentor and protégé, are the same gender, particularly female, the protégé may have high expectations with regards to the relational competence of the sponsor or mentor. A recent study by Hurst, Leberman and Edwards (2017) reveals that while participants initially believed they expected the same things of managers or employees, irrespective of gender, a deeper investigation uncovered gender-based expectations. For example, women expected more emotional support from someone of the same gender. They wanted women managers to offer understanding of the complexities of their lives as well as flexibility and accommodation. The stereotypes around gender had therefore influenced their expectations, without them initially being aware of this.

Hurst, Leberman and Edwards (2017) point to the relational cultural theory (RCT) around human desire for connection with others, with relationships existing within and reproduced in the culture in which they are embedded (Jordan and Walker, 2004). For example, Western society traditionally attributes relationality to women and the concept is thus not gender-neutral. However, Fletcher (2012) warns that these stereotypes are making relational skills "invisible" in the workplace, as they are expected of women anyway. As a result, women are not recognised nor rewarded for their communal behaviour, unless organisations 
acknowledge these consequences of gender stereotypes. Griffin and Reddick's (2011) findings support Fletcher's (2012) notion of gendered expectations of mentors.

Helms, Arfken and Bellar (2016) state that sometimes mentoring and sponsorship are used interchangeably. However, the sponsorship literature highlights the key aspects of power and influence possessed by a sponsor which can help the protégé overcome challenges (FoustCummings, Dinolfo, \& Kohler, 2011). Sponsorship offers women protégés access to established gender-inclusive networks. The current study focusses on sponsorship because of the potentially crucial role it may play, and the limited attention it has received in scholarly studies.

The table below summarises the challenges mentioned above and shows how sponsorship might assist in mitigating these challenges. The first column lists the challenges women face, with relevant references from existing literature. The second column was compiled from the literature review to indicate the potential benefits sponsorship might have to address these challenges. This column also includes the authors' inferences about how sponsorship could play an important role in the advancement of women. The literature referred to in this table included women in general, not specifically ACI women. The extant literature focusses more on the impact of gender than the intersectionality of gender and race with regards to challenges, and how sponsorship - about which there are limited studies - could mitigate the challenges. The inferences about how sponsorship might assist were explored in the semistructured interviews. 


\begin{tabular}{|c|c|}
\hline Challenges faced by women & $\begin{array}{l}\text { Results yielded by sponsorship that can mitigate } \\
\text { challenge }\end{array}$ \\
\hline $\begin{array}{l}\text { Glass Ceiling refers to an invisible barrier } \\
\text { women face when they reach a certain level } \\
\text { in the organisation. (Eagly \& Heilman, 2016) }\end{array}$ & $\begin{array}{l}\text { Sponsor uses position of power and influence to } \\
\text { advocate for and open doors for protégé (Helms, Arfken } \\
\text { \& Bellar, 2016) }\end{array}$ \\
\hline $\begin{array}{l}\text { Old Boys Club refers to a closed network of } \\
\text { predominantly older white men. Access to } \\
\text { this established network is granted to other } \\
\text { men only. (Johnson \& Mathur-Helm, 2011); } \\
\text { (McDonald, 2011) }\end{array}$ & $\begin{array}{l}\text { Sponsor opens up access to his/her networks. Even if } \\
\text { that network is the "Old Boys Club", the protégé will be } \\
\text { welcomed regardless of gender, due to the brand of the } \\
\text { sponsor. (Authors' own inference) }\end{array}$ \\
\hline $\begin{array}{l}\text { Queen Bee Syndrome refers to women in } \\
\text { power denying other women access to the } \\
\text { same success. Perception derived from } \\
\text { women who do not surround themselves with } \\
\text { women in lower ranks. (Derks, Van Laar, \& } \\
\text { Ellemers, 2016) }\end{array}$ & $\begin{array}{l}\text { Sponsor provides critical feedback (Travis, Doty \& } \\
\text { Helitzer, 2013), for example, when protégé behaves } \\
\text { like a Queen Bee. (Authors own inference). Due to the } \\
\text { protégé's connection to the Sponsor, misconceptions } \\
\text { and perceptions may be reduced. (Authors' own } \\
\text { inference) }\end{array}$ \\
\hline $\begin{array}{l}\text { Glass Cliff refers to women leaders obtaining } \\
\text { leadership roles in failing companies or the } \\
\text { role is a set up for failure (Bruckmüller \& } \\
\text { Branscombe, 2011). }\end{array}$ & $\begin{array}{l}\text { Even if a woman leader (protégé) was appointed in a } \\
\text { failing company, the Sponsor advises the protégé, opens } \\
\text { up networks that can also guide protégé. (Authors' own } \\
\text { inference) }\end{array}$ \\
\hline
\end{tabular}

The table summarises for example how the power and influence of the sponsor could open doors for the protégé through giving access to networks.

This literature section has highlighted the focus of current literature on general talent management and its limited attention to sponsorship. It focussed on the role of social identity and the assumption that changes in social identity could result in limited mentoring and/or sponsorship of women protégés.

\section{Methodology}

The study was exploratory and qualitative in nature. Exploratory research is conducted to clarify unclear situations; it is not expected to give definitive confirmation from which to decide a specific strategy (Zikmund, Babin, Carr \& Griffin, 2010). Saunders and Lewis (2012) state that exploratory studies seek to find new data around a theme that is not clearly understood by the researcher. 
Qualitative interviewing explores interviewees' personal experiences and gains a deeper understanding through the interview process (Jännäri \& Kovalainen, 2015). This research was conducted using a semi-structured method.

\section{The rationale for the two-study research design}

Research into sponsorship and social identity of ACI women required a two-study design for a variety of reasons.

Firstly, the phenomenon of a lack of ACI women in top positions in South Africa was of interest to the researchers. To meet the objective of exploring the lived experience of career progression and social identity dynamics of these ACI women in the South African context, the sample had to include C-suite ACI women in South Africa. The researchers wanted to explore specifically which talent development interventions enabled them to progress to the Csuite and, in particular, whether they had been mentoring or sponsoring other ACI women. As ACI women are underrepresented in top management positions (Hills, 2015), the researchers assumed that while these women would be able to reflect on the role of talent development and perhaps sponsorship in particular - in their own career progression, they would have been mentored or sponsored mostly by White males, if at all.

They would thus have limited experience of being mentors or sponsors to other ACI women or of being sponsored by another ACI women. This study was undertaken to explore the phenomenon of sponsorship in particular and the voice of the sponsors was therefore important in offering a nuanced perspective on sponsoring and being sponsored. For this reason, a different sample was required, consisting of 50\% White males. The overall research gained access to the rich interview data of both samples and could extrapolate common themes across the two samples. This design also had limitations which are explored in the Discussion section below. 
The common target population in the two studies consisted of executive level respondents, called C-suite, in corporate organisations. One study consisted of a sample of 29 (14 male and 15 female executives), approximately half of whom were white, and focussed on sponsorship; the second study, consisting of only African, Coloured and Indian (ACI) women executives (23 respondents), focussed more broadly on their development path to the C-suite. Non-probability purposive sampling techniques were used, as the samples were not intended to be statistically representative; instead the selections were based on the characteristics of the samples (Yin, 2015) and the judgment of the researchers (Saunders \& Lewis, 2012)

\section{Study one}

\section{Research questions}

Research question 1: How do corporate executives describe sponsorship?

Research question 2: Did gender play a role in terms of who was better placed to sponsor women or be sponsored?

Research question 3: Did sponsorship contribute to advancement into leadership roles for the executives in this study?

Research sample and coding for Study one: Table 2 offers a summary of the gender, age and industry of the individuals interviewed. The table shows that six were chief executive officers; four chief operational officers; three partners; four board members and two HR directors. 10 of the respondents were older than 50 years. Respondents across all industries were selected, as the researchers wanted to gain a broad view. 19 interviews were conducted face-to-face and 10 were conducted telephonically due to diary or geographical constraints. 
Table 2: Study one: sample characteristics, and perceptions of being sponsored and sponsoring others

Note: The shaded areas highlight female respondents

\begin{tabular}{|c|c|c|c|c|c|c|c|}
\hline No & Age & Gender & Race & Industry & Position & $\begin{array}{l}\text { Being } \\
\text { sponsored }\end{array}$ & $\begin{array}{l}\text { Sponsoring } \\
\text { others }\end{array}$ \\
\hline 1 & 37 & Female & African & IT Consulting & $\mathrm{CEO}$ & Not sponsored & $\begin{array}{l}\text { Not } \\
\text { sponsoring } \\
\text { others }\end{array}$ \\
\hline 2 & 40 & Female & Indian & Law & Partner & $\begin{array}{l}\text { Sponsor } \\
\text { believes in } \\
\text { your potential } \\
\text { and } \\
\text { encourages } \\
\text { growth. }\end{array}$ & $\begin{array}{l}\text { You must } \\
\text { know the } \\
\text { person you are } \\
\text { sponsoring } \\
\text { well. }\end{array}$ \\
\hline 3 & 46 & Male & White & Financial Services & $\mathrm{CEO}$ & $\begin{array}{l}\text { Sponsorship is } \\
\text { at arm's length } \\
\text { and from a } \\
\text { financial } \\
\text { perspective. }\end{array}$ & $\begin{array}{l}\text { Not } \\
\text { sponsoring } \\
\text { others }\end{array}$ \\
\hline 4 & 46 & Female & White & Financial Services & $\mathrm{CEO}$ & $\begin{array}{l}\text { Sponsorship is } \\
\text { protecting } \\
\text { your skin and } \\
\text { believing that } \\
\text { you can take } \\
\text { on a challenge. }\end{array}$ & No comment \\
\hline 5 & 65 & Male & White & Banking & $\mathrm{CEO}$ & $\begin{array}{l}\text { A Sponsor } \\
\text { backs you }\end{array}$ & $\begin{array}{l}\text { If you are too } \\
\text { overt in public } \\
\text { sponsoring, } \\
\text { others get } \\
\text { offended. }\end{array}$ \\
\hline 6 & 47 & Female & African & IT Consulting & $\mathrm{COO}$ & $\begin{array}{l}\text { Sponsor } \\
\text { believes in you } \\
\text { and you are } \\
\text { given } \\
\text { responsibilities }\end{array}$ & $\begin{array}{l}\text { Protégé must } \\
\text { be talented, } \\
\text { but limited } \\
\text { talent } \\
\text { available; } \\
\text { women are } \\
\text { more natural } \\
\text { sponsors, } \\
\text { because their } \\
\text { egos don't get } \\
\text { in the way }\end{array}$ \\
\hline 7 & 44 & Male & African & IT & Head of Sales & $\begin{array}{l}\text { Sponsor raises } \\
\text { you for } \\
\text { specific career } \\
\text { goals }\end{array}$ & $\begin{array}{l}\text { Protégé must } \\
\text { have character } \\
\text { and } \\
\text { competence; } \\
\text { could be over- } \\
\text { dependent }\end{array}$ \\
\hline 8 & 38 & Female & & Financial Services & Executive & $\begin{array}{l}\text { Sponsorship } \\
\text { part of } \\
\text { structured } \\
\text { programme, he } \\
\text { advocates for } \\
\text { me and gives } \\
\text { me access to } \\
\text { networks and } \\
\text { lifts my } \\
\text { profile* }\end{array}$ & $\begin{array}{l}\text { Protégé must } \\
\text { be serious and } \\
\text { committed; } \\
\text { when women } \\
\text { progress, } \\
\text { communities } \\
\text { progress }\end{array}$ \\
\hline
\end{tabular}




\begin{tabular}{|c|c|c|c|c|c|c|c|}
\hline & & & African & & & $\begin{array}{l}\text { Mentioned a } \\
\text { male sponsor }\end{array}$ & \\
\hline 9 & 58 & Female & White & Law & Partner & $\begin{array}{l}\text { Sponsor helps } \\
\text { you to grow }\end{array}$ & $\begin{array}{l}\text { Resources are } \\
\text { limited when } \\
\text { sponsoring } \\
\text { others; women } \\
\text { are better } \\
\text { sponsors } \\
\end{array}$ \\
\hline 10 & 44 & Male & White & Manufacturing & $\mathrm{MD}$ & $\begin{array}{l}\text { Sponsor does } \\
\text { not have to be } \\
\text { someone you } \\
\text { work with }\end{array}$ & $\begin{array}{l}\text { Protégé should } \\
\text { have an open } \\
\text { mind. }\end{array}$ \\
\hline 11 & 43 & Female & White & Banking & $\begin{array}{l}\text { Head of Cash } \\
\text { Investments }\end{array}$ & $\begin{array}{l}\text { Sponsor is } \\
\text { public } \\
\text { supporter }\end{array}$ & $\begin{array}{l}\text { Protégé should } \\
\text { be someone to } \\
\text { believe in }\end{array}$ \\
\hline 12 & 53 & Male & African & Banking/Telecoms & Board Member & $\begin{array}{l}\text { Sponsor avails } \\
\text { his networks }\end{array}$ & $\begin{array}{l}\text { Protégé must } \\
\text { be talented }\end{array}$ \\
\hline 13 & 47 & Female & White & Banking & Chief Economist & $\begin{array}{l}\text { Sponsor } \\
\text { promotes and } \\
\text { supports }\end{array}$ & $\begin{array}{l}\text { The whole } \\
\text { organisation } \\
\text { should be } \\
\text { involved, so it } \\
\text { is problematic }\end{array}$ \\
\hline 14 & 46 & Male & White & Health & $\mathrm{CFO}$ and $\mathrm{COO}$ & $\begin{array}{l}\text { Sponsor } \\
\text { knows the } \\
\text { protégé well; } \\
\text { has loyalty to } \\
\text { the person and } \\
\text { goes out of his } \\
\text { way. }\end{array}$ & $\begin{array}{l}\text { Protégés have } \\
\text { unrealistic } \\
\text { expectations } \\
\text { about taking } \\
\text { them under } \\
\text { your wing. }\end{array}$ \\
\hline 15 & 56 & Male & African & SARS & Group Exec & $\begin{array}{l}\text { Sponsor opens } \\
\text { doors. }\end{array}$ & $\begin{array}{l}\text { There is } \\
\text { limited time to } \\
\text { sponsor }\end{array}$ \\
\hline 16 & 43 & Female & White & Financial Services & HR Exec & $\begin{array}{l}\text { Sponsor } \\
\text { carries the } \\
\text { light for you to } \\
\text { fit in and } \\
\text { promote what } \\
\text { you are } \\
\text { capable of. }\end{array}$ & $\begin{array}{l}\text { Sometimes } \\
\text { people are } \\
\text { sponsored that } \\
\text { should not be. }\end{array}$ \\
\hline 17 & 54 & Male & White & Motor & Country Chair & $\begin{array}{l}\text { Sponsors } \\
\text { advancement } \\
\text { of career and } \\
\text { influence } \\
\text { decisions. }\end{array}$ & $\begin{array}{l}\text { Protégés must } \\
\text { be } \\
\text { enthusiastic; } \\
\text { sometimes } \\
\text { they do not } \\
\text { paddle for } \\
\text { themselves; } \\
\text { you cannot do } \\
\text { it for them. }\end{array}$ \\
\hline 18 & 53 & Female & Indian & Media & Partner & No comment & No comment \\
\hline 19 & 44 & Female & Indian & Accounting & Director & No comment & No comment \\
\hline 20 & 56 & Female & African & IT & Sales Head & $\begin{array}{l}\text { Sponsor assists } \\
\text { to progress } \\
\text { career. }\end{array}$ & No comment \\
\hline 21 & 63 & Male & Indian & Mining & $\begin{array}{l}\text { Chairman of } \\
\text { Board }\end{array}$ & $\begin{array}{l}\text { Sponsorship is } \\
\text { giving } \\
\text { bursaries. }\end{array}$ & $\begin{array}{l}\text { Protégé must } \\
\text { have human } \\
\text { dignity }\end{array}$ \\
\hline 22 & 44 & Male & & $\begin{array}{l}\text { Telecoms/Financial } \\
\text { Services }\end{array}$ & Board Member & No comment & $\begin{array}{l}\text { Protégé must } \\
\text { not have } \\
\text { entitlement; }\end{array}$ \\
\hline
\end{tabular}




\begin{tabular}{|c|c|c|c|c|c|c|c|}
\hline & & & African & & & & $\begin{array}{l}\text { Once the door } \\
\text { is opened, they } \\
\text { need to use it. }\end{array}$ \\
\hline 23 & 45 & Male & White & Manufacturing & $\mathrm{COO}$ & $\begin{array}{l}\text { Sponsor is in } \\
\text { your corner } \\
\text { and has direct } \\
\text { influence. }\end{array}$ & $\begin{array}{l}\text { To sponsor } \\
\text { effectively we } \\
\text { need support } \\
\text { from the top }\end{array}$ \\
\hline 24 & 46 & Female & White & Banking & Head of HR & $\begin{array}{l}\text { Sponsor opens } \\
\text { doors and } \\
\text { influence } \\
\text { networks. }\end{array}$ & $\begin{array}{l}\text { Protégé must } \\
\text { have self- } \\
\text { awareness }\end{array}$ \\
\hline 25 & 47 & Male & Indian & Banking & $\begin{array}{l}\text { National Head of } \\
\text { Banking }\end{array}$ & $\begin{array}{l}\text { Sponsor and } \\
\text { mentor are all } \\
\text { leaders who } \\
\text { should support } \\
\text { the people they } \\
\text { lead. }\end{array}$ & $\begin{array}{l}\text { You have } \\
\text { limited time } \\
\text { for } \\
\text { sponsorship, } \\
\text { so what about } \\
\text { those not } \\
\text { included. }\end{array}$ \\
\hline 26 & 63 & Male & White & Manufacturing & $\begin{array}{l}\text { Retired/Executive } \\
\text { Coach }\end{array}$ & No comment & $\begin{array}{l}\text { Protégé must } \\
\text { have cultural } \\
\text { fit and } \\
\text { sponsorship } \\
\text { requires } \\
\text { support from } \\
\text { other } \\
\text { executives } \\
\end{array}$ \\
\hline 27 & 46 & Female & White & Financial Services & $\mathrm{CEO}$ & $\begin{array}{l}\text { Sponsor sees } \\
\text { potential in } \\
\text { others that } \\
\text { they don't see } \\
\text { in themselves. }\end{array}$ & $\begin{array}{l}\text { Protégé must } \\
\text { want it - be a } \\
\text { hard worker }\end{array}$ \\
\hline 28 & 40 & Female & African & Mining & $\mathrm{CRO}$ & No comment & $\begin{array}{l}\text { Protégé must } \\
\text { be humble }\end{array}$ \\
\hline 29 & 57 & Male & White & Banking/Telecoms & $\begin{array}{l}\text { Ex COO/Head of } \\
\text { Strategy }\end{array}$ & $\begin{array}{l}\text { Sponsor not } \\
\text { helping } \\
\text { personally, just } \\
\text { helping you } \\
\text { open doors. }\end{array}$ & $\begin{array}{l}\text { Protégé must } \\
\text { have } \\
\text { leadership } \\
\text { potential; } \\
\text { sometimes } \\
\text { they have an } \\
\text { inability to use } \\
\text { the } \\
\text { opportunity. }\end{array}$ \\
\hline
\end{tabular}

* One respondent mentioned a formal sponsorship programme at their organisation.

The raw data from the 29 interviews was transcribed in preparation for analysis. Atlas.ti software was utilised for coding, reducing (families) and networks (relationship) stages with the process flow to answer the research questions. Initially, no filters were applied to the coding process to ensure that complete coding was achieved. A total of 165 codes were developed. Densification then resulted in a total of 29 consolidated codes. 


\section{Study two}

\section{Research questions}

Research question 1: What were the critical factors that enabled ACI women to progress to the C-suite?

Research question 2: What were the factors that led to the respondents' interest or disinterest (support or lack thereof) in developing aspirant ACI C-suite women?

\section{Research sample and coding for Study two}

In this study, the researchers conducted 23 face-to-face interviews with ACI women in C-suite roles, despite eight interviews being the minimum prescribed by McCracken (1988) to reach saturation point. There were 12 African and two Coloured women and the rest were Indian; nine women were over 50; the rest younger. There were four chief executive officers, six chief financial officers, six human resource heads and the remaining seven were from various disciplines, such as engineering, supply chain and governance. The table below gives a summary of the sample characteristics.

\section{Table 4: Study two: sample characteristics}

Note: All females in sample. Some women in the sample were from the public sector. These are indicated with an asterisk $(*)$ in the industry column.

Respondents who exhibited queen bee behaviours during interviews and in their coded comments are marked in the table with an ${ }^{\wedge}$ (to indicate a "crown") in the "Mentoring others" column. Those who exhibited queen bee characteristics tended NOT to be involved in mentoring others.

Respondents with Board responsibilities are marked in the position column with an \&.

\begin{tabular}{|l|l|l|l|l|l|l|}
\hline No & Age & Race & $\begin{array}{l}\text { Industry and size of } \\
\text { organisation (number } \\
\text { of employees) }\end{array}$ & Position & $\begin{array}{l}\text { Being } \\
\text { mentored }\end{array}$ & $\begin{array}{l}\text { Mentoring } \\
\text { others }\end{array}$ \\
\hline 1 & $>50$ & African & $\begin{array}{l}* \text { International Fund } \\
5000\end{array}$ & $\begin{array}{l}\text { Chief Executive } \\
\text { Officer }\end{array}$ & $\begin{array}{l}\text { No } \\
\text { mentor }\end{array}$ & $\begin{array}{l}\wedge \text { Formal } \\
\text { programme }\end{array}$ \\
\hline 2 & $>$ & African & $\begin{array}{l}\text { Telecommunications } \\
19200\end{array}$ & $\begin{array}{l}\text { General Manager } \\
\&\end{array}$ & $\begin{array}{l}\text { Male } \\
\text { mentor }\end{array}$ & $\begin{array}{l}\text { Informal } \\
\text { mentoring }\end{array}$ \\
\hline
\end{tabular}




\begin{tabular}{|c|c|c|c|c|c|c|}
\hline 3 & $>50$ & African & $\begin{array}{l}\text { Oil and gas } \\
30100\end{array}$ & $\begin{array}{l}\text { Human Resource } \\
\text { Executive \& }\end{array}$ & $\begin{array}{l}\text { Male } \\
\text { mentor }\end{array}$ & $\begin{array}{l}\text { Informal } \\
\text { mentoring }\end{array}$ \\
\hline 4 & $>50$ & African & $\begin{array}{l}\text { IT services and } \\
\text { consulting company } \\
46000\end{array}$ & $\begin{array}{l}\text { General Manager } \\
\&\end{array}$ & $\begin{array}{l}\text { No } \\
\text { mentor }\end{array}$ & $\begin{array}{l}\text { Informal } \\
\text { mentoring }\end{array}$ \\
\hline 5 & $\begin{array}{l}> \\
50\end{array}$ & African & $\begin{array}{l}* \text { Occupational Health } \\
1779\end{array}$ & $\begin{array}{l}\text { Human Resource } \\
\text { Executive \& }\end{array}$ & $\begin{array}{l}\text { Male } \\
\text { mentor }\end{array}$ & $\begin{array}{l}\text { Informal } \\
\text { mentoring }\end{array}$ \\
\hline 6 & $\begin{array}{l}< \\
50\end{array}$ & African & $\begin{array}{l}\text { Oil and gas } \\
30100\end{array}$ & General Manager & $\begin{array}{l}\text { Male } \\
\text { mentor }\end{array}$ & $\begin{array}{l}\text { Informal } \\
\text { mentoring }\end{array}$ \\
\hline 7 & $\begin{array}{l}< \\
50\end{array}$ & African & $\begin{array}{l}\text { Engineering } \\
572\end{array}$ & $\begin{array}{l}\text { Chief Executive } \\
\text { Officer }\end{array}$ & $\begin{array}{l}\text { Male } \\
\text { mentor }\end{array}$ & $\begin{array}{l}\text { Formal } \\
\text { programme }\end{array}$ \\
\hline 8 & $\begin{array}{l}< \\
50\end{array}$ & African & $\begin{array}{l}\text { Entertainment } \\
432\end{array}$ & General Manager & $\begin{array}{l}\text { Male } \\
\text { mentor }\end{array}$ & $\begin{array}{l}\wedge \wedge \text { No } \\
\text { mentoring }\end{array}$ \\
\hline 9 & $\begin{array}{l}< \\
50\end{array}$ & African & $\begin{array}{l}\text { Engineering } \\
30739\end{array}$ & General Manager & $\begin{array}{l}\text { Female } \\
\text { mentor }\end{array}$ & $\begin{array}{l}\wedge \wedge \\
\text { Informal } \\
\text { mentoring }\end{array}$ \\
\hline 10 & $\begin{array}{l}< \\
50\end{array}$ & African & $\begin{array}{l}\text { Oil and gas } \\
30100\end{array}$ & General Manager & $\begin{array}{l}\text { Male } \\
\text { mentor }\end{array}$ & $\begin{array}{l}\wedge \wedge \\
\text { Informal } \\
\text { mentoring }\end{array}$ \\
\hline 11 & $\begin{array}{l}< \\
50\end{array}$ & African & $\begin{array}{l}* \text { Service } \\
447\end{array}$ & $\begin{array}{l}\text { Human Resource } \\
\text { Executive \& }\end{array}$ & $\begin{array}{l}\text { Male } \\
\text { mentor }\end{array}$ & $\begin{array}{l}\text { Informal } \\
\text { mentoring }\end{array}$ \\
\hline 12 & $\begin{array}{l}< \\
50\end{array}$ & African & $\begin{array}{l}\text { Financial services } \\
54767\end{array}$ & $\begin{array}{l}\text { Human Resource } \\
\text { Executive \& }\end{array}$ & $\begin{array}{l}\text { Female } \\
\text { mentor }\end{array}$ & $\begin{array}{l}\text { Informal } \\
\text { mentoring }\end{array}$ \\
\hline 13 & $\begin{array}{l}> \\
50\end{array}$ & Coloured & $\begin{array}{l}* \text { Government agency } \\
8151\end{array}$ & $\begin{array}{l}\text { Human Resource } \\
\text { Executive \& }\end{array}$ & $\begin{array}{l}\text { No } \\
\text { mentor }\end{array}$ & $\begin{array}{l}\text { Formal } \\
\text { programme }\end{array}$ \\
\hline 14 & $\begin{array}{l}> \\
50\end{array}$ & Coloured & $\begin{array}{l}\text { Retail sector } \\
18561\end{array}$ & $\begin{array}{l}\text { Chief Executive } \\
\text { Officer }\end{array}$ & $\begin{array}{l}\text { Male } \\
\text { mentor }\end{array}$ & $\begin{array}{l}\text { Informal } \\
\text { mentoring }\end{array}$ \\
\hline 15 & $\begin{array}{l}> \\
50\end{array}$ & Indian & $\begin{array}{l}\text { Oil and gas } \\
30100\end{array}$ & $\begin{array}{l}\text { Chief Financial } \\
\text { Officer \& }\end{array}$ & $\begin{array}{l}\text { Male } \\
\text { mentor }\end{array}$ & $\begin{array}{l}\text { Informal } \\
\text { mentoring }\end{array}$ \\
\hline 16 & $\begin{array}{l}> \\
50\end{array}$ & Indian & $\begin{array}{l}\text { Oil and gas } \\
30100\end{array}$ & $\begin{array}{l}\text { Human Resource } \\
\text { Executive \& }\end{array}$ & $\begin{array}{l}\text { Male } \\
\text { mentor }\end{array}$ & $\begin{array}{l}\text { Informal } \\
\text { mentoring }\end{array}$ \\
\hline 17 & $\begin{array}{l}< \\
50\end{array}$ & Indian & $\begin{array}{l}* \text { Financial Services } \\
50\end{array}$ & $\begin{array}{l}\text { Chief Financial } \\
\text { Officer }\end{array}$ & $\begin{array}{l}\text { Male } \\
\text { mentor }\end{array}$ & $\begin{array}{l}\text { Formal } \\
\text { programme }\end{array}$ \\
\hline 18 & $\begin{array}{l}< \\
50\end{array}$ & Indian & $\begin{array}{l}\text { Oil and gas } \\
30100\end{array}$ & $\begin{array}{l}\text { Chief Financial } \\
\text { Officer }\end{array}$ & $\begin{array}{l}\text { Male } \\
\text { mentor }\end{array}$ & $\begin{array}{l}\text { Informal } \\
\text { mentoring }\end{array}$ \\
\hline 19 & $\begin{array}{l}< \\
50\end{array}$ & Indian & $\begin{array}{l}\text { Engineering } \\
800\end{array}$ & $\begin{array}{l}\text { Chief Financial } \\
\text { Officer }\end{array}$ & $\begin{array}{l}\text { Male } \\
\text { mentor }\end{array}$ & $\begin{array}{l}\wedge \wedge \text { No } \\
\text { mentoring }\end{array}$ \\
\hline
\end{tabular}




\begin{tabular}{|l|l|l|l|l|l|l|}
\hline 20 & $\begin{array}{l}< \\
50\end{array}$ & Indian & $\begin{array}{l}\text { Renewable energy } \\
\text { company } \\
7300\end{array}$ & $\begin{array}{l}\text { Chief Financial } \\
\text { Officer }\end{array}$ & $\begin{array}{l}\text { No } \\
\text { mentor }\end{array}$ & $\begin{array}{l}\wedge \wedge \text { No } \\
\text { mentoring }\end{array}$ \\
\hline 21 & $\begin{array}{l}< \\
50\end{array}$ & Indian & $\begin{array}{l}\text { *Engineering } \\
500\end{array}$ & $\begin{array}{l}\text { Chief Financial } \\
\text { Officer \& }\end{array}$ & $\begin{array}{l}\text { Male } \\
\text { mentor }\end{array}$ & $\begin{array}{l}\text { Informal } \\
\text { mentoring }\end{array}$ \\
\hline 22 & $\begin{array}{l}< \\
50\end{array}$ & Indian & $\begin{array}{l}\text { Transportation } \\
700\end{array}$ & $\begin{array}{l}\text { General Manager } \\
\&\end{array}$ & $\begin{array}{l}\text { Male } \\
\text { mentor }\end{array}$ & $\begin{array}{l}\text { Informal } \\
\text { mentoring }\end{array}$ \\
\hline 23 & $\begin{array}{l}< \\
50\end{array}$ & Indian & $\begin{array}{l}\text { Oil and gas } \\
249\end{array}$ & $\begin{array}{l}\text { Chief Executive } \\
\text { Officer \& }\end{array}$ & $\begin{array}{l}\text { Male } \\
\text { mentor }\end{array}$ & $\begin{array}{l}\wedge \text { No } \\
\text { mentoring }\end{array}$ \\
\hline
\end{tabular}

The interview transcripts were analysed utilising Atlas.ti, as prescribed by Friese (2014). The researchers developed a number of codes from the literature review. They coded all 23 transcripts and, as themes emerged, documented them into "families". The initial analysis encompassed 385 codes and nine families. Codes which appeared similar were merged, reducing the number of codes to 226 . The point of saturation was reached at the twelfth transcript; however, the researchers continued to add additional codes when the experiences of the respondents differed.

The results section deals first with the results of Study one and thereafter the results of Study two.

\section{Results for study one}

The interviews commenced with general questions to gauge respondents' understanding of the concept of sponsorship. Sample questions include, "what does your current role entail?"; "what enabled you to reach your current position?" and "what is your view on what mentoring and sponsorship entail?"

Results for research question 1: How do corporate executives describe sponsorship? 
17 respondents sufficiently articulated the definition of sponsorship. Two respondents understood sponsorship to mean financial backing of individuals as opposed to advocacy of potential talent. Assessment of the respondents' definitions of sponsorship showed the most common verbalised themes were advocacy, public support, networks and influence. The figure below illustrates these relationships between themes; for example, advocating unrecognised talent was linked to public support and also influence on career decisions.

Figure 1: Characteristics of sponsorship relationship

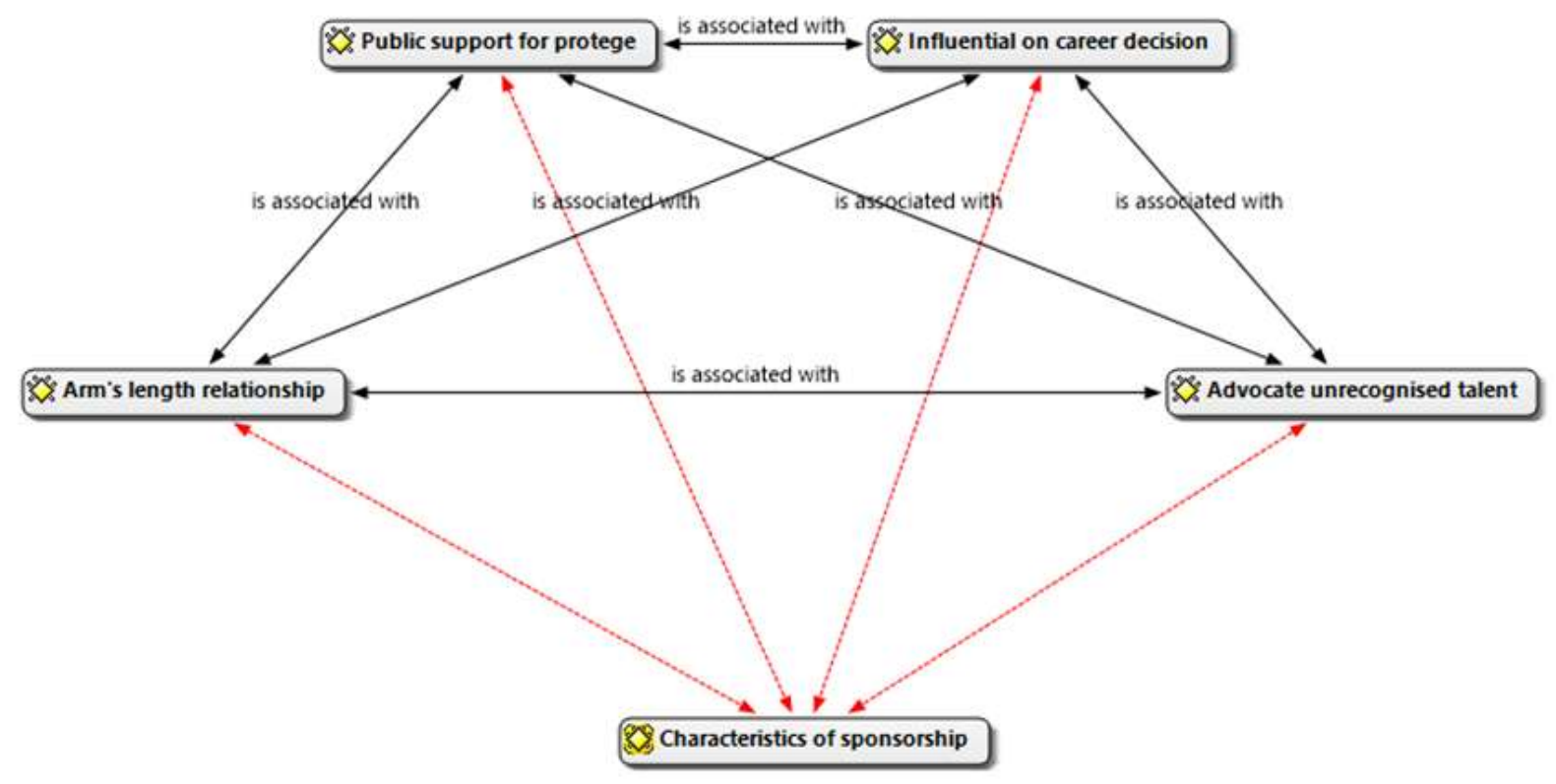

These four themes are described in more detail below, with some quotes from the respondents.

Theme 1: Sponsorship involves advocating for unrecognised talent

"Sponsorship is about, 'I know you have the potential, the ability, the leadership qualities and I am going to actively pursue opportunities for you to test that ... which is very different from mentorship" Respondent 2 (Indian female);

"Sponsor is somebody who is helping you with certain resources to grow" Respondent 9 (White female); 
"Somebody with influence, who is able to help connect a person to the right places or to the right people and also a public supporter of the person" Respondent 11 (White female).

The quotes above illustrate that female respondents (regardless of race) emphasised the high expectation of sponsors, which supports the findings of O'Neill and Blake-Beard (2002) that there is a lot at stake for women who engage as a sponsor.

Theme 2: Sponsorship influences careers

Further analysis of the influence of race and/or gender on the respondents' perceptions revealed that while the African respondents highlighted these high expectations, the African male respondents in particular commented on the boundaries of the relationship, in accordance with the findings of Griffin and Reddick (2011).

"A Sponsor raises you for specific career goals"; and warned: "A protégé must have character and competence, and might become dependent" Respondent 7 (African male).

Table 2 lists other comments from African male respondents, showing self-protection in their relationships with their protégés. Respondent 22, for example, mentioned that "A protégé must not have entitlement; once the door is opened, they must use it" and Respondent 25 commented "You have limited time to sponsor".

Theme 3: Sponsorship could be an arm's length relationship

"Sponsorship is more from a financial perspective and is much more arm 's length" Respondent 3 (White male)

This comment, by a White male respondent, supports previous findings on the male tendency to have distant helping relationships (Griffin \& Reddick, 2011).

Theme 4: Sponsorship involves public support 
"There's people that actually will be different in a meeting because they know other people in the meeting have got their back"; "A sponsor backs you, either overtly or covertly" Respondent 6 (African female);

"Someone who can open a door for you and really give you their backing. Access to networks" Respondent 12 (African male).

A deeper analysis of the respondents' quotes, in particular those about the influence of race on their orientation towards sponsorship, revealed that the African respondents, regardless of their gender, experienced public support from their sponsors. This finding will receive further attention under the discussion of research question 3.

In line with these findings, Sieling (2001) posits that life is a process of advocacy, where either consciously or unconsciously people advocate for or against things. This is particularly true in the workplace. One of the clear messages advocacy sends out is support for the cause or person being advocated. Table 2 illustrates some perceptions of the sample with quotes per respondent on being sponsored or sponsoring others. Interestingly, in analysing the 29 respondents' perceptions of sponsorship, the authors observed that the male respondents tended to highlight task-orientated aspects and more distant relationships, like one spoke about "sponsorship at arm's length" and another about "financial sponsorship, without personal contact"; or "sponsorship is very much a hierarchical thing"; whereas the female respondents generally mentioned the relational aspects, such as "believing in potential" and being a "light to help fit in". Admittedly, Study 1 consisted of a small sample and these results cannot be generalised to the population, however, these observations were in line with general masculine and feminine tendencies, as explained in the literature review. In table 2 these comments are offered according to male and female respondents. The rows with female respondents were shaded for easy reference. Only one respondent mentioned a formal sponsorship programme 
in the organisation and is marked with an asterisk (*). In terms of the differences between sponsorship and mentoring, a respondent observed, "Sponsorship is mentoring on steroids, meaning that the sponsor makes sure you go places".

Results for research question 2: Did gender play a role in terms of who was better placed to sponsor women or be sponsored?

The respondents were asked questions in the interview about being sponsored and playing the role of sponsor. The answer to the following question will be discussed here: "Have you had a mentor or sponsor and if so, can you share the experience and impact that they had on your career?" Several themes were identified. Due to length restrictions of this paper, the authors have highlighted selected themes relating to being sponsored and sponsoring others.

\section{Theme 1: Being sponsored}

In this study, gender ostensibly did not play a role in whether a respondent was sponsored or not.

Of the sample of 29 respondents (14 men and 15 women), all received sponsorship except for five of them, of which one was a male. Two respondents acknowledged they did not know what sponsorship was and therefore did not actively pursue the opportunity of acquiring a sponsor. There was over-arching acknowledgement by 15 respondents that the position of the sponsor, and appetite to sponsor, were more important than gender. Regardless of the gender of the sponsor, respondents said the relationship between sponsor and protégé was critical as this is an impactful partnership.

Interestingly, the study by Hurst, Leberman and Edwards (2017) is relevant here, as the respondents may have been unaware of the influence of gender on their expectations of having sound relationships with a sponsor. In Hurst et al.'s (2017) study, the participants initially believed that they expected the same things of a manager or employee irrespective of gender. 
However, closer inspection revealed gender-based expectations; for example, women were perceived as more relational.

The authors took a closer look at the respondents' comments and discovered that gender does indeed matter:

"Women would more naturally sponsor because their ego don't get in the way, but the boss I work for today doesn't feel like a very egotistical guy so it's not happening to me now and then I think even the political environment it is the women in the right position to be a good sponsor, our commercial director is probably the best sponsor you want in the group because she commands so much power" Respondent 6 (African female);

“Men don't have time when they look at a woman it's about what am I going to get out of her that is that....they have not been good sponsors either mentors or sponsors towards women, but they are very helpful when it comes to other men" Respondent 9 (White female);

"Women are better leaders because we women, you looking after people, you look after your children well, so you also look after people at work well" Respondent 9 (White female);

"When women progress, communities progress" Respondent 8 (African female).

The gender-based expectations of male and female sponsors are clear in the above quotes, since the nurturing and "natural" sponsoring or mentoring inclination is usually attributed to women. The contradiction in this finding was an interesting and surprising aspect of the results in this study. See figure below for a visual illustration of themes and their connections, derived from the interview data analysis with Altas ti software. 


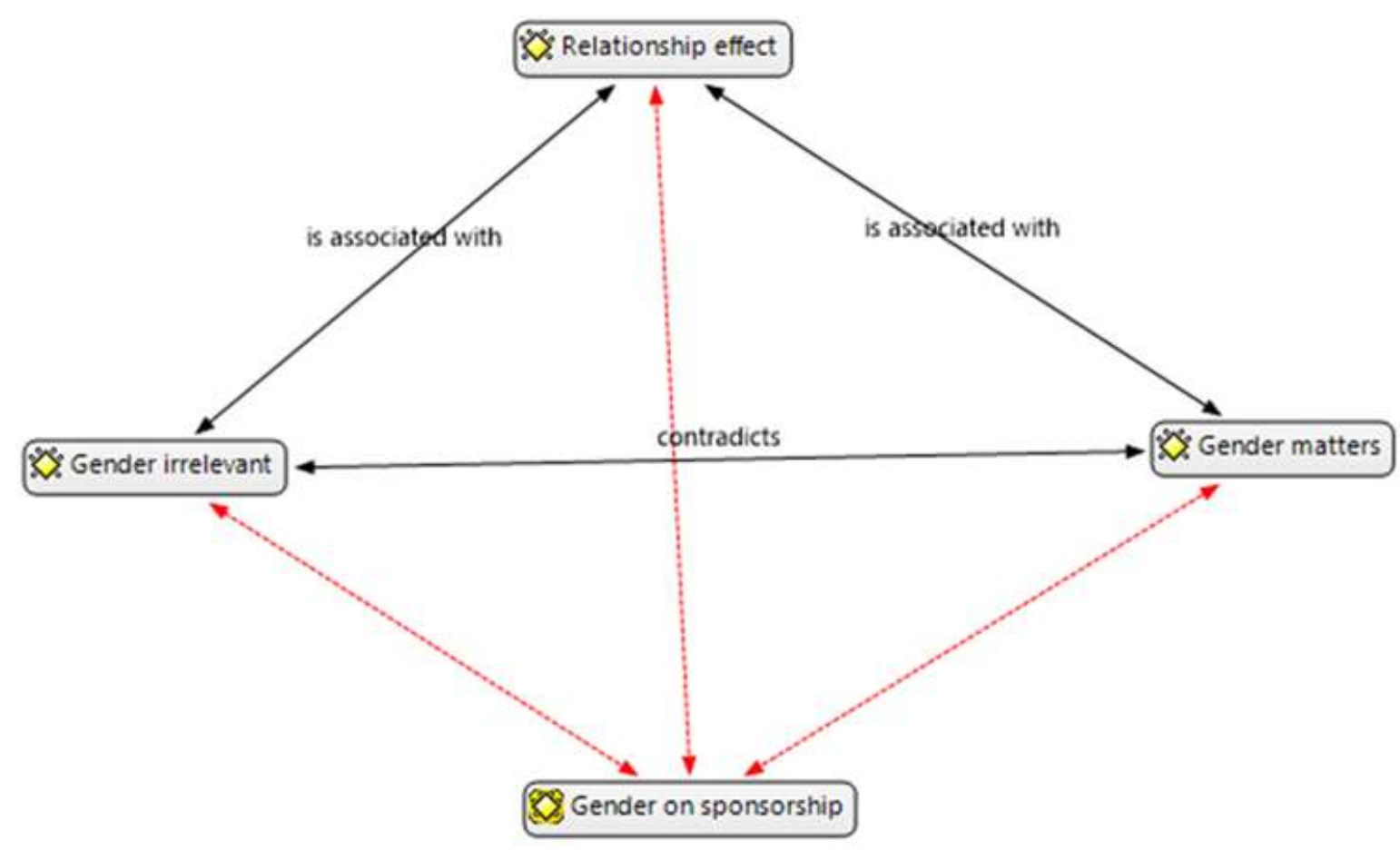

The figure shows that respondents reported that gender was irrelevant in choosing a sponsor, but sometimes gender did indeed matter (as shown in the quotes above); for instance, the notion that women are better leaders and contribute to the progress of communities. Nonetheless, the relationship between sponsor and protégé had an important effect on sponsorship. Women were perceived as more nurturing and interested in the development of others, which made them better sponsorship material.

One respondent cautioned, however, that sponsorship relationships across gender run the risk of crossing the boundaries of professionalism. This observation links with previous studies, like the earlier work of Ragins and Scandura (1994), and later studies, such as Griffin and Reddick (2011) and O'Neill and Blake-Beard (2002), on the danger of sexual attraction, real or perceived, of cross gender relationships. This observation points out one of the limitations of the sponsorship relationship in cases where clear and concise expectations are 
not set out. If expectations are laid out at the outset, these could mitigate the potential risk of breach of professionalism.

Several male respondents felt strongly that because women are trying to navigate through a male-dominated world, and because there is a critical mass of senior male leaders, it is essential for women to have a male sponsor. Respondents argued that because of the malefemale dynamic, and a lack of understanding between the genders, it is necessary for women to secure male sponsors who can advocate for female talent and "translate" to their male peers both the plight and success of female talent. In line with these findings, Bickel (2014) states that because men have occupied leadership roles for much longer, and have had more exposure, opportunity and influence, they actually make better mentors to women. Nonetheless, the current study revealed mixed perceptions about whether male sponsors were more beneficial than female sponsors; however, because there are more males on C-suite levels, there are more male sponsors available, in line with the findings of O'Neill and Blake-Beard (2002).

\section{Theme 2: Sponsoring others}

Respondents were also asked to relate their experience of sponsoring others, for example: "Have you been a sponsor to anyone? And if so, discuss your experience".

The respondents reported that they did not take gender into account when they chose who to sponsor. However, through closer investigation, it seems that the respondents had gendered expectations of protégés when choosing who to sponsor; for example, the drive and confidence mentioned below are agentic qualities, related to the masculine leadership style (Eagly \& Carli, 2011).

Respondents identified the following characteristics required of protégés:

"Confidence is more important than gender" Respondent 14 (White male); 
"Character and competence" Respondent 7 (African male);

"They need the hunger and the drive and then I think positive attitude. I can't work with negative people" Respondent 11 (White female);

"I think the most important quality is humility, you know the realisation that it's not about them that they are part of something greater - when you see people doing something because it's the right thing to do because it makes a difference. That appeals to me that sincerity that authenticity" Respondent 28 (African female).

In this regard, the study by Kumra (2017) is relevant, since she found that merit is in fact far from being an objective measure of ability. In the South African context, with its history of Apartheid and oppression of ACI people, it is indeed important to take note of Kumra's (2017) findings. The persistent lack of racial and gender equality points to embedded inequalities and the need for wider societal understanding of meritocracy. The initial finding of emphasis on merit - and no differences with regard to gender or race when choosing a protégé - was therefore viewed with caution in this study. Interestingly, the male respondents mentioned task-related aspects more often than the female respondents, who in turn emphasised more relational aspects. This finding illustrates the subtle impact of the gender of respondents on their perceptions of what they would look for in protégés and reinforces the gender-based expectations of protégés, in line with Hurst et al (2017) prior research findings. Organisations would benefit from taking note of how gender influences perceptions of merit and genderbased expectations. Remaining unaware of these influences would perpetuate gender and race inequality at senior management levels.

As illustrated in Table 2, six respondents could not relate situations in which they sponsored others. As the comments show, there were high expectations of protégés in cases where respondents were indeed sponsoring others. In addition to gender, race was also not explicitly 
mentioned as a dimension when choosing who to sponsor. Although half of the sample were White executives, they did not report a conscious effort to sponsor ACI people or women in particular. This is disconcerting as current inequalities will persist if the current top management incumbents do not target talented ACI women for sponsorship. Race is explored in more detail in the Study two discussion below.

Results for research question 3: Did sponsorship contribute to advancement into leadership roles for the executives in this study?

The majority of respondents acknowledged that sponsorship enabled them to advance into leadership roles, with some respondents clearly stating that a sponsor saw their potential and opened doors. Several themes were identified under this research question, including sponsorship enabling leadership development. The following quote illustrates the career development offered to a female by a male sponsor:

"I've got someone in business now who through a very structured programme has been appointed my sort of internal coach slash sponsor and he is completely removed from anything that I do on a daily basis. So he is the head of strategy for emerging markets, he is senior enough in the organisation that he sits on boards that I don't have access to at this stage in my career. And because I have a relationship with him, he has exposed me to his network and he advocates for me, so he sees what I can do and he speaks about me, you know, in those circles that I am not in and for me I think that a sponsor is someone that lifts your profile in the organisation and actually helps grow your career in that sense" Respondent 8 (African female).

This quote illustrates the finding that the African respondents in this study had experienced the support of sponsorship in their career progression. The researchers acknowledge that the qualitative nature of the study prohibits generalisation to the whole 
population; however, the trends in the deeper analysis are interesting and worth noting for further investigation in future studies.

The mechanism by which sponsorship influenced careers of the respondents included, "protection against other influential managers", when these managers wanted to damage the career of the protégé; "acceleration of one's advancement curve, since the sponsor pulls you up"; "sponsor backs you, when you are a maverick" and a "sponsor is hands on".

To gain a balanced view of the benefits of sponsorship for career advancement, respondents were also asked, "what in your view are some of the limitations of sponsorship?"

In response, 21 respondents identified a variety of themes, categorised as limitations to sponsorship. One theme that was highlighted was unclear expectations. Six respondents described an inability to use opportunities provided by sponsorship as a limitation. Time constraints were also cited as one of the key limitations to sponsorship. This is mainly because sponsorship was performed within the leadership role, and both sponsor and protégé had limited time to engage. As sponsorship is about supporting and advocating for potential talent, the respondents indicated that it was necessary to have buy-in by top management.

"I suppose for sponsorship it's got to be something in an organisation that's brought in by everyone that needs to be part of the process from the CEO down the chain" Respondent 13 (White female).

If women reach certain levels, they are not evaluated in the same way as men:

"Women tend to reach a ceiling - with positions beyond a certain level being male-dominated" Respondent 5 (White male);

"The ratio of male to female in leadership ranks validates the bias toward the male in these positions" Respondent 7 (African male). 
The table below list the limitations or challenges of sponsorship, as identified by respondents, in the first column. The second column offers the authors' recommendations for sponsors, protégés and organisations to address these challenges.

Table 3: Actions required of sponsors, protégés and organisations to address challenges in sponsorship

\begin{tabular}{|l|l|}
\hline $\begin{array}{l}\text { Challenges in sponsorship as } \\
\text { mentioned by respondents }\end{array}$ & $\begin{array}{l}\text { Actions required of sponsors, protégés and } \\
\text { organisations (compiled by authors) }\end{array}$ \\
\hline $\begin{array}{l}\text { Inability to use opportunity: } \\
\text { For example, the sponsor may } \\
\text { open doors/create opportunities } \\
\text { for the protégé, but the protégé } \\
\text { does not use the opportunity. }\end{array}$ & $\begin{array}{l}\text { Clear, concise and consistent expectations are required } \\
\text { about what sponsorship entails and investment and return } \\
\text { on investment. }\end{array}$ \\
\hline $\begin{array}{l}\text { Time constraints: Both the } \\
\text { sponsor and the protégé have } \\
\text { limited time available. }\end{array}$ & $\begin{array}{l}\text { Clarity on the investment of time is required as part of the } \\
\text { expectations conversations. }\end{array}$ \\
\hline $\begin{array}{l}\text { Lack of top management buy-in: } \\
\text { As the outcome of sponsorship } \\
\text { is the career advancement of the } \\
\text { protégé, it is important that there } \\
\text { is buy-in and a belief in value as } \\
\text { an outcome. }\end{array}$ & $\begin{array}{l}\text { The sponsor must not only advocate for the protégé, but } \\
\text { also for the management development tool of sponsorship. } \\
\text { The advocacy of sponsorship could be substantiated with } \\
\text { felivery from protégés. } \\
\text { Sponsorship could be a requirement of senior leaders. }\end{array}$ \\
\hline $\begin{array}{l}\text { Too overt: } \\
\text { The sponsorship relationship is } \\
\text { too open and perceived as } \\
\text { favouritism. }\end{array}$ & $\begin{array}{l}\text { The advocacy of the protégé should be less public to avoid } \\
\text { unintended harm to the protégé. }\end{array}$ \\
\hline $\begin{array}{l}\text { Culture: The culture of the } \\
\text { organisation is not conducive to/ } \\
\text { supportive of sponsorship. }\end{array}$ & $\begin{array}{l}\text { Due to the sponsor's position of power, he/she has the } \\
\text { ability to cultivate a developmental culture. }\end{array}$ \\
\hline
\end{tabular}

(Authors' own compilation of recommendations)

For example, sponsorship requires support from top management and a change in culture. Ely, Ibarra and Kolb (2011) posit that corporates have been attempting to fix the gender parity issue with numbers or by ticking boxes. The real solution, however, is rooted deeper in the culture of the organisation and behaviours of leaders. For example, from January 2017, all listed entities in South Africa need to have a policy on the promotion of gender diversity at board level, as well as disclose how they are performing against this policy (Smith, 2016). It could be worthwhile to explore sponsorship as a mechanism to address this gap; however, sponsorship is a management tool that requires the buy-in and advocacy of the very people who potentially created and thrive in the male-dominated environment. The act of sponsorship nonetheless sends a clear message to the rest of the organisation, as well as the sponsor's networks, that he or she backs this potential talent. In summary, study one illustrated that the 
sponsorship relationships were formally contracted, but not part of a formal organisational programme, except in one respondent's case.

\section{Results for study two}

Results for research question 1: What were the critical factors that enabled ACI women to progress to the C-suite?

The questions asked of respondents in connection with this research question included, "What were the critical factors that enabled you to progress to the position you are today, namely the C-suite?"; "Did you experience barriers? If yes, which were the two or three - internal or external - barriers that were the most overwhelming in your journey?"

The majority of respondents insisted that they worked twice as hard as their male counterparts. Ten participants believed they were the sole reason for their own success, as illustrated by the following quote: "I think every time I crossed a particular milestone I always grew even bigger. When I graduated against all odds, money and all, my voice grew - I knew I was special." Respondent 14 (Coloured female)

Three respondents attributed their success to their religious beliefs: "You build credibility, people respect you and start to assimilate your ideas more easily and start to accept you as a person.” Respondent 12 (African female).

The majority of respondents retained their authenticity by remaining true to their value systems and did not compromise themselves to fit into the male-dominated society: "I haven't lost the essence of who I am as a person, so you try to influence the culture in that regard, but obviously fitting with the culture and how things are done within the environment." Respondent 14 (Coloured female); 
“As a woman... you don't have to change yourself and operate like a man for you to occupy a certain position..." Respondent 22 (Indian female).

In certain instances, the ACI women changed their persona to adapt to the White leadership norm: "I've always been accused of being White, but I think for me I only get accused of that because I never want to do stuff that typically belong to any particular group..." Respondent 11 (African female);

"... as black men, as well, who come from the place where there was "Baas" [Afrikaans word for 'Boss']... that is going to take a while to go away and no matter how middle-class we can be, how educated we can be, there is that subconscious belief that white is correct, first." Respondent 15 (Indian female).

These quotes illustrate the prominence of race in the social identity of these ACI women. Corlett and Mavin (2014) highlight the intersectionality of gender with other social identities and warn against treating all identities equally. The finding about the prominence of race in the sample group is aligned to the notion that race as social identity remains important in the South African context.

These respondents confessed to being task masters because they needed to prove they deserved a seat at the table, for example, by wearing pin-striped suits to fit into the social norm, thereby confirming that dark-coloured suits are associated with seniority. According to the coded transcripts, there were 77 instances where respondents themselves or women they have come across have adapted the male persona to survive in the organisation. The leadership norm was leading through fear, especially in these instances, where women adopt their personas. The respondents concurred that even when women adapt to the agentic leadership norm, they are not completely accepted socially by men. In the literature review, the concept backlash was explained, where women who were agentic were not accepted (Rosette \& Tost, 2010). These 
factors could be damaging for women as they would only be partially accepted by each group, meaning that they must prove themselves to their in-group as well as the out-group, never really belonging to any specific group and thus having various social identities (Tajfel \& Turner, 1979).

During the dawn of democracy in South Africa, the out-group was ACI women. The women we interviewed however, no longer associated their self-esteem with a racial group, illustrating the change in social identity. It is interesting to note that they continue to encounter double jeopardy in terms of race and gender but they no longer view race as a deciding factor; instead, they view their self-identity as having moved on. Nonetheless, race remains a reference point in terms of where they moved from and other South Africans still use race in categorising ACI women. Furthermore, the unity described by Ashforth and Mael (1989) has developed into unity with other women or other men. The difference between the self-identities of women who have moved away from the social identity dimension of race, and how other people still perceive them mainly as members of specific race groups, illustrates the complexities and nuances in the intersectionality research domain.

The respondents who migrated to agentic behaviours, as described by Eagly and Carli (2007), have compromised both their race and gender while ascending the corporate ladder. This is aligned to Park's (2013) view, whereby comparisons with the past reduce racial or gender barriers as women perceive themselves as more equal to their white male counterparts and feel less association with their previous out-group.

In summary, the enabling factors, according to the respondents, were: working hard; building credibility and retaining it; authenticity; remaining true to femininity and refraining from adapting to the male persona for survival in the workplace; and resilience in the face of adversity. 
Another important critical success factor mentioned by ACI women in Study two was the type of support given and received by them. Table 5 shows the results of the analyses, according to type of support given and received. It is interesting that age made a difference to how prepared ACI women were to offer time and energy for coaching and mentoring others; columns indicating age groups are therefore included. For example, the first row shows there were seven African women who were above 50, as well as seven Indian women above 50. Those younger than 50 consisted of five African, two Coloured and two Indian women. The older women were more likely to mentor others.

\section{Table 5: Type of support given and received}

Note: The shaded row shows the respondents per group; the remainder of the table is based on different respondent's quotes or responses within that group, coded according to themes.

\begin{tabular}{|c|c|c|c|c|c|c|}
\hline Grouping of respondents & $\begin{array}{r}\text { African } \\
<\mathbf{5 0} \\
\end{array}$ & $\begin{array}{r}\text { Indian } \\
<50 \\
\end{array}$ & $\begin{array}{r}\text { African } \\
>\mathbf{5 0} \\
\end{array}$ & $\begin{array}{r}\text { Coloured> } \\
\mathbf{5 0} \\
\end{array}$ & $\begin{array}{r}\text { Indian } \\
>\mathbf{5 0} \\
\end{array}$ & Total \\
\hline Respondents in each category & 7 & 7 & 5 & 2 & 2 & 23 \\
\hline Mentoring or coaching by others & 12 & 5 & 11 & - & 3 & 31 \\
\hline Mentoring or coaching others & 21 & 7 & 24 & 2 & 8 & 62 \\
\hline Mentored: by women & 1 & 4 & 13 & - & 3 & 21 \\
\hline Mentored: by men & 8 & 4 & 8 & 1 & 4 & 25 \\
\hline No mentoring & 4 & 2 & 2 & - & - & 8 \\
\hline $\begin{array}{l}\text { Mentors challenged them in their } \\
\text { careers }\end{array}$ & 8 & 3 & 4 & 3 & 4 & 22 \\
\hline Mentors used coaching style & 3 & - & 1 & 1 & - & 5 \\
\hline General mentoring comments & 8 & 7 & 6 & - & 1 & 22 \\
\hline Total & 65 & 32 & 69 & 7 & 23 & 196 \\
\hline
\end{tabular}

The table shows that offering mentoring and coaching to others exceeded receiving mentoring and coaching by others by twofold. The respondents have numerous ways in which they assist others in their aspiration to the $\mathrm{C}$-suite. The vast majority of the respondents stated they assist women, through either succession planning, nominating them for challenging tasks or encouraging them to further their education: "So it's also just lifting as we climb and putting 
our hand out to help others as well, you know if each one of us did that, we'd already live in a better place." Respondent 12 (African female).

The respondents reported that mentors contributed to their careers, supporting the work of scholars such as Kao, Rogers, Spitzmueller, Lin and Lin (2014). There was one respondent who disagreed with the authors because her mentor, who was allocated to her in a formal organisational setting, demonstrated to her what bad management encompasses. In this instance, Tajfel and Turner's (1979) said that mentors constrain experience of subordinates to acquire critical knowledge, to ensure that the division between the in-group and the out-group continues. Same gender relationships for two of the respondents supported the work of Kao et al. (2014) who state that similarity between mentor and mentee forms an emotional connection. These two respondents found it more fulfilling to be mentored by a woman because the mentor understands the difficulty around raising a family, building a career and being a woman; thus, the learning addresses all spheres of life. Men tend to place greater emphasis on career when mentoring (Kao et al, 2014) and the majority of the respondents confirmed this.

The interviewees were aware that they have an advantage as the employment equity legislation is in their favour; and they acknowledged their marketability. The majority of respondents over the age of 50 acknowledged that they were fortunate at the time the legislation was implemented to be able to pursue stretch opportunities because they were educated women. The respondents' race, ethnicity and culture contributed to their perseverance as they were products of the Apartheid system, which in itself created resilience: "I think the fact that government enforced certain rules...I ensured the fact that I'm black, the fact that I'm female - works for me.” Respondent 6 (African female).

The respondents agreed that their colleagues perceived their appointments as efforts by their organisations to meet employment equity targets. This resulted in them having to prove themselves within the organisation to gain respect. These respondents concur that they have 
encountered incidents of "double jeopardy", a term meaning being convicted twice for the same offence. In this instance, being African firstly and a woman secondly, made the working environment arduous. Below are extracts from the respondents' descriptions of their experiences: "I must say, actually, that XXX is one company that made me feel black and a woman," and "So I do feel it, but no-one has ever openly, obviously, said those things" Respondent 11 (African female);

"People might view you as, you know "she's black, she's a woman, we appointed her because of the employment equity purposes." Ok, so you now have to work extra hard to move people from that perception...” Respondent 14 (Coloured female).

Interestingly, many respondents stated that women do not lobby other women and do not bounce ideas off one another; instead, they request buy-in from men as the authority in the executive committee.

Results for research question 2: What are the factors that have led to the interest or disinterest (support or lack thereof) in developing aspirant ACI C-suite women?

The questions that the interviewer asked the respondents in connection with this research question include, "How would you describe yourself or what forms your identity?"; "How would you describe your leadership style?"; "What level of support do you provide to your potential C-suite ACI women?"

The majority of the respondents had a community culture as they were growing up, but this seems to have disappeared as their identities migrated to the new, socially acceptable leadership norm. The respondents were aware of their differences to the leadership norm and that the system requires them to confront and overcome these differences: "I am committed to building organisations and ultimately a society based on values of equality, of democracy, of 
fairness and equity. I will continue to pursue the agenda of getting women into the mainstream of business." Respondent 9 (African female).

Respondent 9 stated that no support was provided for her throughout her career, but she is determined to plough back by sharing her story with other women to ensure they do not encounter the same challenges, or if they do, they learn from them. Social identity threats incline the group to stronger identification (Park, 2013). These respondents no longer associated themselves as strongly with their racial as they did with their gender group, as the threats are stronger with regard to gender. It is interesting to note that Tajfel and Turner's (1979) theory is proved to be true by these participants; they changed their perceptions of lowand high-status groups. Previously, the high-status groups were whites, but since migrating to the C-suite there is more perceived equality (Park, 2013) and the high-status groups have evolved to men.

The respondents noted that their male and white counterparts progressed within the organisation at an accelerated pace compared to their sluggish progress. Their introspection as a result of this made the respondents question their abilities and negatively impacted their confidence. The challenge that these women face is that they are misrepresented by age, gender and racial lines before they even open their mouths. The majority of respondents confirmed that they were generally the only ACI woman at the table in a sea of white men. There were instances where respondents described the mentorship or coaching as formalised through the organisation. These instances are where respondents are not directly involved in the structuring of these programs as business dictates this. These programs appear to be around general challenges women encounter in the workplace or regarding the difficulty balancing home with work. They reported mixed effectiveness of these programmes. 
In the table below, the authors illustrated that there were 124 quotations of queen bee behaviour amongst all the respondents, meaning behaviour that they encountered during their career paths that resembles the theoretical examples of queen bee. The authors coded these references to queen bee into the behavioural categories as well as which of the different age and ACI groups experienced these behaviour in other women.

Table 6: Reporting of "queen bee" behaviours

Note: The shaded row shows the respondents per group; the remainder of the table is based on different respondent's quotes or responses within that group, coded according to behaviours of queen bee.

\begin{tabular}{|c|c|c|c|c|c|c|}
\hline $\begin{array}{l}\text { Queen bee characteristics as } \\
\text { described by respondents }\end{array}$ & $\begin{array}{l}\text { African } \\
>\mathbf{5 0}\end{array}$ & $\begin{array}{l}\text { Coloured } \\
>\mathbf{5 0}\end{array}$ & $\begin{array}{l}\text { Indian } \\
>\mathbf{5 0}\end{array}$ & $\begin{array}{l}\text { African } \\
<\mathbf{5 0}\end{array}$ & $\begin{array}{l}\text { Indian } \\
<\mathbf{5 0}\end{array}$ & Total \\
\hline Respondents per category & 5 & 2 & 2 & 7 & 7 & 23 \\
\hline Me, myself incorporated & 10 & 3 & 1 & 16 & - & 30 \\
\hline $\begin{array}{l}\text { Compete with each other as opposed } \\
\text { to the system collectively }\end{array}$ & 6 & 3 & - & 15 & - & 24 \\
\hline $\begin{array}{l}\text { Compete instead of lifting each other } \\
\text { up }\end{array}$ & 7 & 4 & - & 9 & - & 20 \\
\hline Does not add diversity & 4 & 3 & 2 & 6 & - & 15 \\
\hline Feel intimidated by competition & 5 & 2 & - & 7 & - & 14 \\
\hline More harmful than men & 3 & 2 & - & 7 & - & 12 \\
\hline Lack of humility & 1 & 2 & - & 2 & - & 5 \\
\hline $\begin{array}{l}\text { Promote men over women who are } \\
\text { competent }\end{array}$ & 2 & - & - & 2 & - & 4 \\
\hline Total & 38 & 19 & 3 & 64 & - & 124 \\
\hline
\end{tabular}

The observed behaviour relating to queen bee had a low frequency compared to the total codes. Nonetheless, three respondents experienced having queen bees as their managers. They said the queen bees felt threatened by another intelligent ACI woman, so did everything in their power to discredit the respondents. One of the respondents said the queen bee with whom she interacted had a multitude of White subordinates because she was scared an ACI would supersede her. The table illustrates that the group of Indian respondents below 50 years have not encountered queen bee syndrome; and the ones above 50 years have only mentioned 
it three times. This is interesting as the African respondents, greater and less than 50 years have experienced this phenomenon frequently as well as the two Coloured women.

In addition to the responses about queen bee behaviours, the authors observed specific behaviours that respondents mentioned about themselves that reflected queen bee behaviours. For example, for example the tendency to be highly competitive and not wanting other women to progress. The authors found it interesting that the women who demonstrated queen bee characteristics, as described in the interviews, were generally the ones who did not volunteer their time for mentoring or coaching others. The respondents who reflected queen bee characteristics had mainly White managers as subordinates. The respondents who achieved board status did not demonstrate queen bee characteristics, except for two outliers. The authors inferred that the women on boards were comfortable with themselves and did not feel the need to compete.

The respondents that have shown passion for developing other women, were aware that they were ultimately accountable for assisting other women to progress in their careers. For example, a respondent stated that no support was provided for her throughout her career, but she is determined to plough back by sharing her story with other women to ensure they do not encounter or learn from the same challenges. The authors found a sense of gratitude for the opportunities that they received through their careers, a religious orientation and humbleness in these women who were keen to mentor others.

As described above, study one revealed that sponsorship could assist in mitigating the challenges women leaders face in their advancement towards senior roles. These challenges are even more pronounced in the case of ACI women and as a result, the findings of the first study are relevant to these women. 
To summarise, the overlap and differences between sponsorship and mentoring are listed in the table below:

Table 7: Comparison table between sponsorship and mentorship

\begin{tabular}{|c|c|c|c|}
\hline No & Dimensions & \multicolumn{2}{|c|}{$\begin{array}{c}\text { Sponsorship and Mentoring } \\
\text { (Inferred from both Study } 1 \text { and } 2 \text { findings) }\end{array}$} \\
\hline 1 & $\begin{array}{l}\text { Mechanism to } \\
\text { assist }\end{array}$ & \multicolumn{2}{|c|}{ Offer advice } \\
\hline 2 & Type of support & \multicolumn{2}{|c|}{ Provide emotional support } \\
\hline 3 & $\begin{array}{l}\text { Experience and } \\
\text { status }\end{array}$ & \multicolumn{2}{|c|}{ Experienced and influential } \\
\hline 4 & Access to networks & \multicolumn{2}{|c|}{ Give access to networks } \\
\hline & & $\begin{array}{l}\text { Sponsorship } \\
\text { (Inferred from Study } 1 \text { findings) }\end{array}$ & $\begin{array}{l}\text { Mentoring } \\
\text { (Inferred from Study } 2 \text { findings) }\end{array}$ \\
\hline 5 & Risk taking & Places own reputation on the line & $\begin{array}{l}\text { Does not place self on the line - no } \\
\text { risk }\end{array}$ \\
\hline 6 & Proximity & $\begin{array}{l}\text { Mostly from same organisation as } \\
\text { protégé: close proximity, where } \\
\text { sponsor has political clout }\end{array}$ & $\begin{array}{l}\text { Mostly from different organisation } \\
\text { from protégé: } \\
\text { could be distant and have political } \\
\text { clout there }\end{array}$ \\
\hline 7 & Nature of support & Offers public support & $\begin{array}{l}\text { Offers private support: behind the } \\
\text { scenes }\end{array}$ \\
\hline 8 & $\begin{array}{l}\text { Stakes in success of } \\
\text { protégé }\end{array}$ & $\begin{array}{l}\text { Has vested interest in success of } \\
\text { protégé }\end{array}$ & $\begin{array}{l}\text { Has no vested interest in success of } \\
\text { protégé }\end{array}$ \\
\hline 9 & $\begin{array}{l}\text { Return on } \\
\text { investment }\end{array}$ & Seeks return on personal investment & $\begin{array}{l}\text { Has no requirement to receive return } \\
\text { on personal investment }\end{array}$ \\
\hline 10 & $\begin{array}{l}\text { Guarantee } \\
\text { protégé's talent }\end{array}$ & $\begin{array}{l}\text { Advocates and pledges or guarantees } \\
\text { protégé's talent }\end{array}$ & $\begin{array}{l}\text { Advocates, but does not guarantee } \\
\text { protégé's talent }\end{array}$ \\
\hline 11 & $\begin{array}{l}\text { Nature of financial } \\
\text { support }\end{array}$ & $\begin{array}{l}\text { Offers financial support and could } \\
\text { sponsor courses and organise stretch } \\
\text { assignments with high visibility }\end{array}$ & $\begin{array}{l}\text { Does not offer financial support or } \\
\text { necessarily sponsor courses or } \\
\text { organise stretch assignments }\end{array}$ \\
\hline 12 & $\begin{array}{l}\text { Focus of } \\
\text { development } \\
\text { support }\end{array}$ & $\begin{array}{l}\text { Focused on career development of } \\
\text { protégé }\end{array}$ & $\begin{array}{l}\text { Focused on personal and career } \\
\text { development of protégé }\end{array}$ \\
\hline 13 & $\begin{array}{l}\text { Nature of } \\
\text { relationship }\end{array}$ & $\begin{array}{l}\text { Mostly contracted proactive formal } \\
\text { relationship }\end{array}$ & Sometimes informal relationship \\
\hline
\end{tabular}

(Authors' own compilation, based on findings from Studies 1 and 2)

The two studies offered examples of how sponsors and mentors give advice and support; whereas sponsorship has a public support element, mentoring is mostly behind the scenes. The table also illustrates that there could be informal mentoring relationships, while sponsorship is generally a proactive contracted more formal agreement and entails financial sponsorship and organising visible stretch assignments. 


\section{Consolidated themes}

In summary, some of the themes revealed across the two studies include: selecting sponsors or mentors; engaging in sponsorship or mentoring of others; queen bee characteristics; and finally, social identity issues. Table 8 offers a summary of these themes and findings per study as well as recommendations for organisations.

Table 8: Consolidated themes from Studies one and two; implications and recommendations for organisation

\begin{tabular}{|c|c|c|c|c|}
\hline No & Themes & $\begin{array}{l}\text { Study 1: } 29 \text { different } \\
\text { gender and race } \\
\text { respondents. } \\
\text { Focused on } \\
\text { sponsorship }\end{array}$ & $\begin{array}{l}\text { Study 2: } 23 \text { only ACI women } \\
\text { respondents. } \\
\text { Focused on mentoring }\end{array}$ & $\begin{array}{l}\text { Implications and } \\
\text { recommendations for } \\
\text { organisations }\end{array}$ \\
\hline 1 & $\begin{array}{l}\text { Selecting } \\
\text { sponsors or } \\
\text { mentors }\end{array}$ & $\begin{array}{l}\text { Respondents reported } \\
\text { that gender did not } \\
\text { play a role when } \\
\text { choosing sponsor; } \\
\text { however, on closer } \\
\text { inspection, gender- } \\
\text { based expectations } \\
\text { were revealed }\end{array}$ & Male mentors were preferred & $\begin{array}{l}\text { In cases where ACI } \\
\text { women require } \\
\text { development, they would } \\
\text { prefer to be paired with } \\
\text { male mentors }\end{array}$ \\
\hline 2 & $\begin{array}{l}\text { Engaging in } \\
\text { sponsorship or } \\
\text { mentoring of } \\
\text { others }\end{array}$ & $\begin{array}{l}\text { Gender and or race } \\
\text { ostensibly did not } \\
\text { play a role in } \\
\text { choosing protégés. } \\
\text { However, closer } \\
\text { inspection revealed } \\
\text { gender-based } \\
\text { expectations, for } \\
\text { example, high drive } \\
\text { and confidence. } \\
\text { Sponsors had high } \\
\text { expectations of } \\
\text { protégés. } \\
\text { Male respondents } \\
\text { emphasised task- } \\
\text { related aspects and } \\
\text { females relational } \\
\text { aspects }\end{array}$ & $\begin{array}{l}\text { Gender and race generally did } \\
\text { not play a role for ACI women } \\
\text { when choosing who to mentor } \\
\text { and they mostly had informal } \\
\text { relations with protégés. There } \\
\text { were exceptions though, and } \\
\text { some were passionate about } \\
\text { mentoring other ACI women. } \\
\text { Age played an important role: } \\
\text { the older, the more likely to } \\
\text { mentor. } \\
\text { Just less than half of the } \\
\text { sample perceived their own } \\
\text { hard work as the reason for } \\
\text { their success and thus were not } \\
\text { interested in mentoring others }\end{array}$ & $\begin{array}{l}\text { Organisations that require } \\
\text { women development } \\
\text { need to initiate } \\
\text { programmes and ensure } \\
\text { an adequate number of } \\
\text { women in the talent pool } \\
\text { to be mentored or } \\
\text { sponsored }\end{array}$ \\
\hline 3 & $\begin{array}{l}\text { Queen bee } \\
\text { characteristics }\end{array}$ & $\begin{array}{l}\text { Limited reference to } \\
\text { queen bee } \\
\text { characteristics }\end{array}$ & $\begin{array}{l}\text { Low frequency of responses } \\
\text { around queen bee, yet eight of } \\
\text { the } 23 \text { respondents exhibited } \\
\text { behaviour associated with } \\
\text { queen bees }\end{array}$ & $\begin{array}{l}\text { Organisations must } \\
\text { monitor whether C-suite } \\
\text { women are mentoring } \\
\text { other women and identify } \\
\text { those with queen bee } \\
\text { behaviours to be coached } \\
\text { and monitored to limit the } \\
\text { damage they can cause }\end{array}$ \\
\hline 4 & $\begin{array}{l}\text { Social identity } \\
\text { issues }\end{array}$ & $\begin{array}{l}\text { A couple of the } \\
\text { female respondents } \\
\text { were aware of an in- }\end{array}$ & $\begin{array}{l}\text { The ACI women sample was } \\
\text { highly aware of losing their } \\
\text { identity in order to fit in and }\end{array}$ & $\begin{array}{l}\text { Organisations must be } \\
\text { more aware and initiate } \\
\text { focused discussion }\end{array}$ \\
\hline
\end{tabular}




\begin{tabular}{|l|l|l|l|}
\hline & $\begin{array}{l}\text { and out-group, based } \\
\text { on gender }\end{array}$ & $\begin{array}{l}\text { that they were still perceived } \\
\text { as the out-group }\end{array}$ & $\begin{array}{l}\text { forums for ACI women to } \\
\text { share issues around } \\
\text { identity. A culture of } \\
\text { equality has to be } \\
\text { cultivated to ensure } \\
\text { inclusive work } \\
\text { environments }\end{array}$ \\
\hline
\end{tabular}

\section{Selecting sponsors or mentors}

The individual sponsor's position of power, access to networks and ability to influence made for a better sponsor in the Study one sample. Sponsors thus did not purposefully sponsor talented women, since gender ostensibly did not play a role in their choice of protégé. This is a surprising finding in the context of corporate South Africa, where there is a legal requirement to increase numbers of senior women. However, closer investigation revealed that sponsors had gender-based expectations, as explained in the results section. This is concerning, as gender inequality will not be rectified without the support and sponsorship of executives. Gender differences with regard to perceptions also revealed that male respondents perceived sponsorship more as task-based actions, such as introducing protégés to networks, whereas female respondents focussed on relational elements. The second study, while focussing on mentoring, confirmed the orientation of male mentors to focus on careers and in this study, the ACI women actually preferred male mentors. These findings further reinforce the gender-based expectations of sponsors and mentors.

\section{Engaging in sponsorship or mentoring of others}

Sponsorship requires public advocacy and high commitment from sponsors, causing them to have high expectations of protégés. Herein lies the main difference from mentoring.

While sponsorship includes mentoring, mentors do not necessarily sponsor their protégés. For example, in cases where mentors intend to sponsor a protégé, they have to use their power to advocate or pledge publicly for a protégé to advance her career proactively. The sponsorship 
function thus requires proactive involvement and creation of stretch opportunities to offer visibility to the protégé. Sponsorship thus entails much more than offering support from a distance. For example, a respondent in Study 1 observed that sponsorship means, "I am going to actively pursue opportunities for you". Nonetheless, mentoring and sponsorship overlap (Helms et al, 2016), particularly by offering advice and access to networks from a position of experience and influence.

\section{Queen bee characteristics}

Both studies revealed limited queen bee phenomena, contrary to the Johnson and Mathur-Helm (2011) study. Yet, of the 23 respondents in Study two, eight exhibited queen bee behaviours and they were not inclined to mentor and coach others. Organisations must take notice of this finding when selecting women for the C-suite. Those with queen bee characteristics tend not to assist in growing the pool of ACI women as successors in the C-suite and thus may require additional coaching prior to being selected, or be closely monitored and expected to mentor others.

\section{Social identity issues}

The research supports social identity theory in terms of the in- and out-group hypothesis (Wells \& Aicher, 2013). It also shows there is racial and gender inequality in the South African workplace and that ACI women continue to be shunned through social identity biases, where women are generally considered as the out-group within senior positions in organisations (Mathisen, Ogaard \& Marnburg, 2013).

Study two unearthed the surprising finding that the ACI women's own behaviours led to their career progression. This confirms the resilience of these women to prevail even in the face of adversity or, in their case, double jeopardy. It also indicates that organisations have to select those individuals who demonstrate these resilient qualities for the $\mathrm{C}$-suite positions and 
not assume that these are qualities people can acquire through coaching, mentoring or sponsoring programmes.

Nonetheless, ACI women's difficult backgrounds, have made many women in top positions more empathetic towards the needs of other aspirant $\mathrm{C}$-suite women. This finding makes ACI senior women good candidates for offering development opportunities to junior ACI women, extending Johnson and Mathur-Helm's (2011) argument that women could support other women's development, to include the intersectionality of race and gender. Leadership must ensure that the values upheld by their staff are conducive to challenging traditions within that organisation. This will help women to voice their opinions and take on more active roles in developing others towards advancement to $\mathrm{C}$-suite roles. In closing, organisations must initiate interventions - such as the sponsorship proposed in this paper - to make senior managerial roles more accessible to aspiring women. This would result in higher levels of diversity and inclusion in the boardrooms of corporate South Africa.

\section{Implications for the career progression of women aspiring to the $\mathrm{C}$-suite}

The lack of ACI women in the C-suite has an adverse effect on other ACI women's career aspirations. There might be limited sponsors or mentors available and this study highlights the need for individual women aspiring to the C-suite to find suitable mentors or sponsors. The benefits of sponsorship over mentoring were revealed in this study and, as a result, individual ACI women could test whether their present mentors would be prepared to publicly support them, in the way a sponsor would. Mentors could reassess their roles and consider choosing, from the pool of aspiring candidates, those ACI women who show the most potential. They also need to be aware of how gender may cloud their judgment of merit and of who is worthy of their sponsorship. 
The finding that older ACI women are more prone to develop others should direct individual ACI women to target 50+ women as role models and sponsors. Our finding about the above 50 years' ACI women and those on boards, who were more inclined to mentor others, relates to O'Neill and Blake-Beard's (2002) argument that women would be more reluctant to enter into mentoring relationships, due to the high expectation to show discernment in these relationships, since the above 50 years' ACI women and those on board level, would have less to loose and thus would be more open to mentoring other ACI women. . Time constraints make it essential for sponsors and mentors to have upfront and continuous expectation conversations with their protégés to ensure alignment of goals and a successful sponsorship/ mentoring relationship. Protégés must appreciate that sponsorship/mentoring is only an enabler for advancement into leadership roles; hard work, accountability, humility and other leadership traits remain prerequisites. Protégés who advance into senior leadership roles must pay it forward by sponsoring/ mentoring other up-and-coming talent.

\section{Implications for organisations}

Organisations should collect feedback and regularly monitor whether talented women are being sponsored. In cases where they are not supported in this way, they should initiate more formal organisational processes to pair up sponsors and protégés. The study's findings suggest that organisations should market the benefits of sponsorship by assembling stories of how sponsorship assisted in advancing women's careers. Existing formal mentoring programmes need to place greater emphasis on the sponsorship function specifically, where mentors publicly and proactively advocate for their protégés. In line with Ibarra, Ely \& Kolb’s (2013) findings, the bias that women executives face must be addressed in organisations, by making it explicit and initiating culture change interventions to address discriminatory practices, instead of merely relying on formal mentoring and/or sponsoring programmes. In Study one, only one respondent reported a formal sponsoring programme in their organisation. 
Organisations could recruit women above 50 for formal mentoring programmes and reward and recognise their efforts in mentoring protégés. Study two also revealed that women on boards were more open to offer their time for mentoring, in line with Burke and Collins' (2001) prior research; organisations could benefit from including these women in their mentoring programmes.

Organisations have an important function to raise awareness of, and educate people on, genderbased expectations and perceptions around merit, since Kumra (2017) found that these perceptions could disfavour women in advancing to senior roles, in line with McIntosh et al (2015) and this study's findings.

\section{Research limitations}

The research limitations revolve around the qualitative research being context-specific and not intended to be generalised to a broader population. The two studies had relatively small samples and conclusive assertions about the complex phenomena investigated could not be made. The respondents reported on their own experiences; self-reporting of behaviour has the limitation that respondents may have over-reported their own support of others and underreported how much help they received from mentoring. The impact of response bias introduced by the researchers was minimised by using open-ended questions in a semi-structured interview format, enabling freedom of expression from the respondents. Potential confirmation biases caused by the researchers during the coding process of the open-ended responses were addressed by having all code categories ratified by the appointed research supervisor (Miles, Huberman \& Saldaña, 2013). The two-study design made reporting in one paper difficult, as was extrapolating common themes and reporting on these. The authors had to be selective in choosing quotes and themes to discuss in one paper, which could limit understanding of the 
subtle nuances in the complexity of intersectional social identities from the rich data set available from the total of 52 interviews conducted during the two studies.

\section{Conclusion and future studies}

The research questions revolved around enablers of career advancement for ACI women to the C-suite and changes in their social identity, as well as whether these women would support the advancement of aspiring ACI women. The research revealed interesting nuances and complexities around the women's hardworking resilience and mentoring relationships. ACI women showed a change in their social identity around race and identified more with women and men at senior levels from other racial groups than their own. The women 50 years and older were more inclined to mentor others, showing the importance of age in relation to developing the next generation of ACI C-suite women. With regards to sponsorship, the ACI women sample had limited exposure to public advocacy or sponsorship and reported more on mentoring relationships. The two-study research design highlighted important differences between mentoring and sponsorship.

The research questions in Study two revolved around the impact of gender on sponsorship and how sponsorship might contribute to career advancement. Study two offered insight into the gendered expectations of sponsors and gendered perceptions around merit in identifying protégés worthy of sponsorship. The themes across the two studies were identified with appropriate implications for individual ACI women seeking to pursue senior management roles and organisations which have to support their aspirations.

Further research is required within different contexts to better understand the factors which enabled ACI women to enter leadership positions and their assistance towards other women. The researchers did not interview the respondents' subordinates to gain a perspective of the differences between the respondents' perceived leadership styles versus how their 
subordinates perceived these leadership styles. A longitudinal study to determine if these respondents experience the same perceptions of double jeopardy over time would be interesting. Other avenues for the use of sponsorship and tools to foster inclusivity and acceptance could be investigated, as Helms et al (2006) suggested. Finally, the authors recommend research into the impact on gender equality of sponsors advocating not for a specific woman, but for gender equality as a whole. As the second study illustrated, most female ACI leaders are willing to assume the role of mentor and provide coaching to other women. However, further studies could investigate whether ACI women would be prepared to take mentoring to the public advocacy level in order to sponsor aspiring ACI women.

\section{References}

Appelbaum, S. H., Audet, L. and Miller, J. C. 2003, "Gender and Leadership? Leadership and Gender? A journey through the landscape of theories". Leadership and Organisational Journal, 24(1): 43-51.

Ashforth, B. E. and Mael, F. 1989, "Social identity theory and the organization". Academy of management review, 14(1): 20-39.

Athey, S., Avery, C. and Zemsky, P. 2000, "Mentoring and Diversity". The American Economic Review, 90(4): 765-786.

Bernard-Powers, J. 2008, "Feminism and Gender in Education for Citizenship". Handbook of Education for Citizenship and Democracy. New York: SAGE.

Bickel, J. M. 2014, "How men can excel as mentors of women". Academic Medicine, 89: 1100-1102.

Booysen, L. 2007, "Societal Power Shifts and Changing Social Identities in South Africa". Workplace Implications, South African Joournal of Economic and Management Sciences, 10(1): 1-10.

Bruckmüller, S. and Branscombe, N. R. 2011, "How Women End Up on the 'Glass Cliff'". Harvard Business Review, Jan-Feb, https://hbr.org/2011/01/how-women-end-up-on-the-glass-cliff.Burke, S. and Collins, K. M. 2001, "Gender differences in leadership styles and management skills", Women in Management Review, 16(5): 244-257, https://doi.org/10.1108/09649420110395728.

Carli, L. L. and Eagly, A. H. 2001, "Gender, Hierarchy, and Leadership: An Introduction". Journal of Social Issues, 57(4): 629-636.

Cleaver, J. 2016, October 24. http://businessresearcher.sagepub.com/sbr-1775-1010832757355/20161024/women-in-management.

Corlett, S. and Mavin, S. 2014, "Intersectionality, identity and identity work: Shared tenets and future research agendas for gender and identity studies", Gender in Management: An International Journal, 29(5): 258-276. https://doi.org/10.1108/GM-12-2013-0138

Department of Labour, 2016, 16th Commission for Employment Equity Annual Report. Pretoria: Department of Labour, Republic of South Africa. 
Derks, B., Van Laar, C. and Ellemers, N. 2016, "The queen bee phenonmenon: Why women leaders distance themeselves from junior women". The Leadership Quarterly, 27(3): 456-469.

http://dx.doi.org./10.1016/j.leaqua.2015.12.007.

Eagely, A. H. and Heilman, M. E. 2016, "Gender and Leadership: Introduction to the special issue". The Leadership Quarterly, 26: 349-353.

Eagly, A. H. and Carli, L. L. 2003, "The female leader advantage: An evaluation of the evidence". The Leadership Quarterly, 14: 807-834.

Eagly, A. H. and Carli, L. L. 2007, "Women and the labyrinth of leadership". Harvard Business Review, 85(9): 62, https://hbr.org/2007/09/women-and-the-labyrinth-of-leadership.

Eagly, A. H. and Johannesen-Schmidt, M. C. 2001, "The Leadership Styles of Women and Men". Journal of Social Issues, 57(4): 781-797.

Eagly, A. H. and Karau, S. J. 2002, "Role Congruity Theory of Prejudice Toward Female Leaders". Psychological Review, 109(3): 573-598.

Eagly, A. H., Johannesen-Schmidt, M. C. and van Engen, M. L. 2003, "Transformational, Transactional and Laissez-Faire Leadership Styles: A Meta- Analysis Comparing Women and Men". Psychological Bulletin, 129(4): 569-591.

Elstad, B. and Ladegard, G. 2012, "Women on corporate boards: Key influencers or tokens?" Journal of Management and Governance, 16(4): 595-615. http://doi.org/10.1007/s10997-010-9165-y.

Ely, R. J., Ibarra, H. and Kolb, D. M. 2011, "Taking Gender Into Account: Theory and Design for Women's Leadership Development Programs". Academy of Management Learning \& Education, 10(3): 474-493.

Ensher, E. A. and Murphy, S. E. 1997, "Effects of race, gender, perceived similarity, and contact on mentor relationships". Journal of Vocational Behavior, (50): 460-481. http://doi.org/10.1006/jvbe.1996.1547.

Fernandez, S. and Lee, H. 2016, "The transformation of the South African Public Service: exploring the impact of racial and gender representation on organisational effectiveness". The Journal of Modern African Studies, 54(1): 91-116. http://doi.org/10.1017/S0022278X15000816.

Fitzsimmons, T. W. and Callan, V. J. 2016, "Applying a capital perspective to explain continued gender inequality in the C-suite". The Leadership Quarterly, 27(5): 765-787. doi:10.1016/j.leaqua.2016.05.001.

Fletcher, J.K. 2012, “The relational practice of leadership”, in Uhl-Bien, M. and Ospina, S. (Eds), Advancing Relational Leadership Research: A Dialogue Among Perspectives, Information Age Publishing, Charlotte, NC, pp. 83-106.

Foust-Cummings, H., Dinolfo, S. and Kohler, J. 2011, Sponsoring Women to Success. New York: CATALYST. http://www.catalyst.org/system/files/sponsoring_women_to_success.pdf.

Friese, S. 2014, Qualitative data analysis with ATLAS. ti. SAGE Publications Incorporated.

Griffen, K. A. and Reddick, R. J. 2011, "Surveillance and sacrifice: Gender differences in the mentoring patterns of Black professors at predominantly White research universities". American Educational Research Journal, xx(x): 1-26 DOI: 10.3102/0002831211405025.

Harnois, C. E. 2015, "Age and Gender Discrimination: Intersecting Inequalities across the Lifecourse", in Vasilikie Demos, Marcia Texler Segal (ed.) At the Center: Feminism, Social Science and Knowledge (Advances in Gender Research, Volume 20) Emerald Group Publishing Limited, pp.85 - 109. 
Helms, M. M., Arfken, D. E. and Bellar, S. 2016, "The Importance of Mentoring and Sponsorhip in Women's Career Development". SAM Advanced Management Journal. Society for the Advancement of Management.

https://www.thefreelibrary.com/The+importance+of+mentoring+and+sponsorship+in+women $\% 27 \mathrm{~s}+\mathrm{c}$ areer...-a0469315650

Hills, J. 2015, "Addressing Gender Quotas in South Africa: Women Employment and Gender Equality Legislation". Deakin Law Review, 20(1): 153-184.

Hofmeyer, K. and Mzobe, C. 2012, "Progress towards advancing women in South African Organisations: Myth or Reality". African Journal of Business Management, 6 (4): 1276-1289.

Hogg, M. A. 2001, "A Social Identity Theory of Leadership". Personality and Social Psychology Review, 5 (3): 184-200.

Hurley, D. and Choudhary, A. 2016, "Factors influencing attainment of CEO position for women", Gender in Management: An International Journal, 31(4): 250-265. https://doi.org/10.1108/GM-01-2016-0004

Hurst, J.,Leberman, S. and Edwards, M. (2017) "The relational expectations of women managing women", Gender in Management: An International Journal, Vol. 32 Issue: 1, pp.19-33, https://doi.org/10.1108/GM-02-2016-0016

Ibarra, H., Ely, R., \& Kolb, D. 2013, "Women rising: The unseen barrier". Harvard Business Review, 91(9): 3-8.

Jännäri, J. and Kovalainen, A. 2015, "The research methods used in "doing gender" literature". International Journal of Gender and Entrepreneurship, 7(2): 214-231. http://doi.org/10.1108/IJGE04-2014-0012.

Jordan, J.V., Hartling, L.M. and Walker, M. (Eds) 2004, The Complexity of Connection: Writings from the Stone Center's Jean Baker Miller Training Institute, Guilford Press, New York, NY.

Johnson, Z. and Mathur-Helm, B. 2011, "Experiences with queen bees: A South African study exploring the reluctance of women executives to promote other women in the workplace". South African Journal of Business Management, 42(4): 47-56.

http://reference.sabinet.co.za/sa_epublication_article/busman_v42_n4_a4.

Joo, B. K. B., Sushko, J. S. and McLean, G. N. 2012, "Multiple faces of coaching: Manager-as-coach, executive coaching, and formal mentoring". Organization Development Journal, 30(1): 19.

Kaiser, C. R. and Spalding, K. E. 2015, "Do women who succeed in male-dominated domains help other women? The moderating role of gender identification". European Journal of Social Psychology, 45(5): 599-608. Retrieved from: http://doi.org/10.1002/ejsp.2113.

Kao, K., Rogers, A., Spitzmueller, C., Lin, M. and Lin, C. 2014, "Who should serve as my mentor? The effects of mentor 's gender and supervisory status on resilience in mentoring relationships." Journal of Vocational Behavior, 85(2): 191-203.

Kumra, S. 2017, "Really saying something: Exploring conceptions of merit in women's experience of career based tensions inspired by my friend Ruth Simpson." Gender in Management: An International Journal, 32(7): 468-475. https://doi.org/10.1108/GM-05-2017$\underline{0067}$

Ladegard, G. and Gjerde, S. 2014, "Leadership coaching, leader role-efficacy, and trust in subordinates. A mixed methods study assessing leadership coaching as a leadership development tool." The Leadership Quarterly, 25(4): 631-646. 
Lagerberg, F. 2016, March 8. http://www.grantthornton.global/en/insights/articles/women-inbusiness-2016/.

Lin, W., Wang, L., Bamberger, P. A., Zhang, Q., Wang, H., W., Guo, W., Shi, J. and Zhang, T. 2016, "Leading future orientations for current effectiveness: The role of engagement and supervisor coaching in linking future work self salience to job performance". Journal of Vocational Behavior, 92: $145-156$.

McCallum, S. Y., Forret, M. L. and Wolff, H.-G. 2014, "Internal and External Networking BehaviorAn Investigation of Relationships with Affective, Continuance, and Normative Commitment".

Emerald, 19(5): 596-614.

McCracken, G. 1988, Managing Qualitative Research, 59-65.

McDonald, S. 2011, "What's in the' Old Boys' Network? Accessing Social Capital in Gendered and Racialized Networks". Social Networks, 33: 317-330

McIntosh, B., McQuaid, R. \& Munro, A. 2015, "The impact of gender perceptions and professional values on women's careers in nursing", Gender in Management: An International Journal, 30(1): 2643, https://doi.org/10.1108/GM-12-2013-0135

Miles, M. B., Huberman, A. M. and Saldana, J. 2013, Qualitative data analysis: A methods sourcebook.3 ed. Los Angeles: SAGE Publications Incorporated.

Moodley, L., Holt, T., Leke, A. and Desvaux, G. 2016, "Women Matter Africa: Making gender diversity a reality". McKinsey\&Company. http://www.mckinsey.com/global-themes/womenmatter/women-matter-africa.

Morahan, P. S., Rosen, S. E., Richman, R. C. and Gleason, K. A. 2011, "The Leadership Continuum: A framework for Organizational and Individual Assessment Relative to the advancement of Women Physicians and Scientists". Journal of Womens Health, 1-9.

O'Neill, R. M. and Blake-Beard, S. D. 2002, "Gender barriers to the female mentor - male protege relationship". Journal of Business Ethics, 37(1): 51-63.

O'Reilly, N. D. 2008, "Women helping women: how mentoring can help your business". Supervision, 69 (1): $12-22$.

Park, J. S. 2013, "After pain comes joy: identity gaps in employees' minds". Group Processes \& Intergroup Relations, 43(3): 419-437. https://doi.org/10.1177/1368430214550340.

Ragins, B. R. and Scandura, T. A. 1994, "Gender differences in expected outcomes of mentoring relationships". Academy of Management Journal, 37 (4): 957-971.

Republic of South Africa. Act No. 47 of 2013: Employment Equity Amendment Act, 2013, 2014, The Presidency.

Republic of South Africa. Act No. 53 of 2003: Broad-Based Black Economic Empowerment Act, 2003. The Presidency.

Rosette, A. S. and Tost, L. P. 2010, "Agentic Women and Communal Leadership: How Role Prescriptions Confer Advantage to Top Leaders". Journal of Applied Psychology, 95 (2): 221-235.

Saunders, M. and Lewis, P. 2012, Doing research in business and Management. Pearson: Edinburgh Gate.

Scheepers, C. B. 2012. Coaching Leaders: The 7 P Tools to propel change. Randburg: Knowres.

Sieling, J. G. 2001, "Organizational Advocacy 101". The Journal for Quality and Participation, 24 (1): 42-45. 
Skade, T. 2016, April 13. http://www.destinyconnect.com. Johannesburg, Gauteng, South Africa. http://www.destinyconnect.com/2016/04/13/fewer-women-leadership-positions-sa/

Skaggs, S., Stainback, K. and Duncan, P. 2012, "Shaking things up or business as usual? The influence of female corporate executives and board of directors on women's managerial representation". Social Science Research, 41(4): 936-948.

Smith, C. 2016, August 22. http://www.fin24.com/Special-Reports/Womens-Month-2016/39-of-sabusinesses-have-no-women-leaders-report-20160822-2.

Statistics South Africa 2015, Mid-year population estimates 2015. Pretoria: Department of Labour, Republic of South Africa.

Statistics South Africa 2015, National and provincial labour market: Youth, Q1: 2008-Q1: 2015. Pretoria: Department of Labour, Republic of South Africa.

Tajfel, H. 1978, The social psychology of minorities. London: Minority Rights Group.

Tajfel, H. and Turner, J. C. 1979, "An integrative theory of intergroup conflict, (January 1979), 3347". Psychology of Intergroup Relations. http://doi.org/10.1016/S0065-2601(05)37005-5.

Tajfel, H. and Turner, J. C. 1986, "The social identity theory of intergroup behavior". Psychology of Intergroup Relations, 7-24. Retrieved from: http://doi.org/10.1111/j.1751-9004.2007.00066.x.

Tee Ng, P. 2012, "Mentoring and coaching educators in the Singapore education system". International Journal of Mentoring and Coaching in Education, 1(1): 24-35.

Tran, V., Garcia-Prieto, P. and Schneider, S. C. 2011, "The role of social identity, appraisal, and emotion in determining responses to diversity management". Human Relations, SAGE Publications Incorporated 64(2): 161-176. http://doi.org/10.1177/0018726710377930.

Travis, E. L., Doty, L. and Helitzer, D. L. 2013. Sponsorship: A Path to the Academic Medicine C Suite for Women Faculty. Academic Medicine, 88 (10): 1-4.

Vachon, J. C. 2014, "Tiaras, Queen Bees, Imposters and the Board Room: Lean In and Women in Corporate Givernance". Journal of Business and Technology Law, 3 (30): 279-292.

Wells, J. E. and Aicher, T. J. 2013, "Follow the Leader: A Relational Demography, Similarity Attraction, and Social Identity Theory of Leadership Approach of a Team's Performance". Gender Issues, 30(1-4): 1-14.

World Economic Forum. 2016, October 26. https://www.weforum.org/reports/the-global-gender-gapreport-2016/.

Yin, R. K. 2015, Qualitative research from start to finish. New York: Guilford Publications.

Zikmund, W. G., Babin, B. J., Carr, J. C. and Griffin, M. 2010, Business Research Methods. Canada: South-Western: Cengage Learning. 